\title{
A Facially Coordinating Tris-Benzimidazole Ligand for Nonheme Iron Enzyme Models
}

\author{
Parami S. Gunasekera, ${ }^{[a]}$ Preshit C. Abhyankar, ${ }^{[a]}$ Samantha N. MacMillan, ${ }^{[b]}$ and David C. Lacy ${ }^{*[a]}$
}

[a] Department of Chemistry, University at Buffalo, State University of New York, Buffalo, New York 14260, United States.

E-mail: dclacy@buffalo.edu

[b] Department of Chemistry and Chemical Biology, Cornell University, Ithaca, New York 14853, United States.

Supporting information for this article is given via a link at the end of the document.

\begin{abstract}
Herein, we report a new tripodal tris-benzimidazole ligand (Tbim) that structurally mimics the 3-His coordination environment of certain nonheme mononuclear iron oxygenases. The coordination chemistry of Tbim was explored with iron(II) revealing a diverse set of coordination modes. The aerobic oxidation of biomimetic model substrate diethyl-2-phenylmalonate was studied using the Tbim-Fe and $\mathrm{Fe}(\mathrm{OTf})_{2}$.
\end{abstract}

The mononuclear iron dependent nonheme subclass commonly have an iron center coordinated within a two-histidine one-carboxylate (2-His-1-C) facial triad binding pocket. ${ }^{1,2}$ Additional binding modes have also been discovered, and these include the facial three-histidine (3-His), see-saw three-histidine one-carboxylate, and see-saw four histidine binding modes. ${ }^{3}$ Modelling of the facial 3-His coordination has been accomplished through various nitrogen donor ligands such as 1,4,7triazacyclononane (tacn), ${ }^{4}$ tris(2-pyridyl)methane, ${ }^{5}$ trispyrazolyl variants namely trispyrazolylborates, ${ }^{6}$ trispyrazolylmethanes ${ }^{7}$ and trisimidazolylphosphines (TIP). ${ }^{8}$ Some of these facially coordinating ligands have been used to prepare $\mathrm{Fe}$-based $\mathrm{O}_{2}$ derived oxidants, such as superoxo and oxo species ${ }^{9-14}$ and in catalysis. ${ }^{15,16}$

Despite the successes of these ligands in modeling 3-His coordination, ${ }^{17,18}$ we noted that most the ligands contain donor groups that are not represented in nature (Figure 1). For instance, histidine donors are aromatic nitrogen groups with $\mathrm{sp}^{2}$ hybridized $\mathrm{N}$-atoms. In contrast, tacn has unconjugated $\mathrm{sp}^{3}$ hybridization. Accordingly, we noted that facially coordinating ligands with imidazole and benzimidazole $\mathrm{N}$ donors have been used to mimic facial 2-His-1-C and 3-His coordination modes with iron. ${ }^{19,20}$ For instance, Gebbink and coworkers reported a 2-His-1-C facial triad using imidazole and benzimidazole ligands (2bim1C) with iron. ${ }^{19}$ In another report Fielder and coworkers use TIP, which contains imidazole nitrogen donors, to model the 3 -His facial triad in an iron complex. ${ }^{21}$ It is also noteworthy that, in addition to the electronic similarity (i.e. $\mathrm{sp}^{2}$ hybridized and aromatized), benzimidazole has excellent $\mathrm{p} K_{\mathrm{a}}$ similarities to histidine. For instance, the $\mathrm{p} K_{\mathrm{a}}$ of the nitrogen donor of histidine is 6.0 in water, ${ }^{22}$ which is close to the $\mathrm{p} K_{\mathrm{a}}$ of 6.6 for 1,2-dimethylbenzimidazole that is the donor moiety in Gebbink's 2bim1C ligand. ${ }^{23,24}$ This is also in contrast to a $\mathrm{pK}$ of 7.69 for 4 -

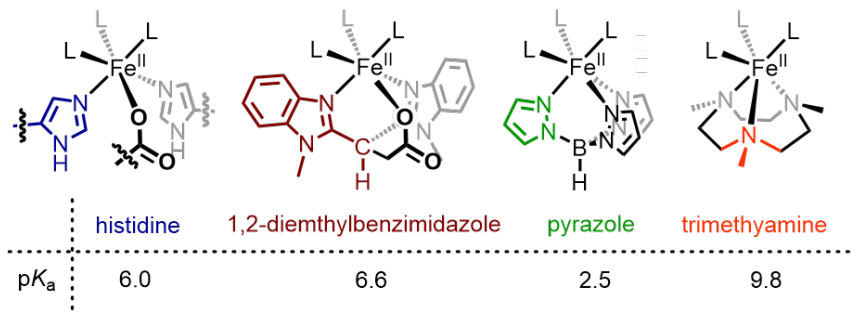

Figure 1. Natural $2 \mathrm{H} 1 \mathrm{C}$ enzyme binding site (left) compared to tridentate ligands with representative "mono-dentate" ligand donor groups and their respective $[\mathrm{NH}]^{+} p K_{a}$ in water (see Fig. S19 and Table S1).

methylimidazole. ${ }^{25}$ While differences may be superficial, ligands can impart a certain set of appropriate thermodynamic properties required for dioxygen reactivity. ${ }^{26}$ Herein, we report the synthesis of a novel 3-His model with a tris-benzimidazole ligand, 2,2'-(2-(1ethylbenzimidazol-2yl)ethane-1,1-diyl)bis(1-

methylbenzimidazole) (Tbim), its coordination with iron, and a brief foray into catalysis.

Synthesis of the new ligand Tbim used a strategy inspired by the one Gebbink used to prepare 2bim1C (Scheme 1). ${ }^{20,27,28}$ With ligand in hand, we explored the coordination chemistry of Tbim using a variety of $\mathrm{FeX}_{2}$ salts $(\mathrm{X}=\mathrm{OAc}, \mathrm{Cl}$, OTf) (Scheme 2 \& 3). Treatment of Tbim with $\mathrm{Fe}(\mathrm{OAc})_{2}$ or $\mathrm{Fe}(\mathrm{Cl})_{2}$ in an acetonitrile solvent mixture afforded new complexes from which crystals suitable for diffraction revealed the mono-ligated complexes [Fe $\{$ Tbim $\left.\}(X)_{2}\right](\mathbf{1}, \mathrm{X}=\mathrm{OAc} ; \mathbf{2}, \mathrm{X}=\mathrm{Cl})$ (Figure 2). The complexes show paramagnetically shifted ${ }^{1} \mathrm{H}$ NMR signals in the range -20 ppm to 90 ppm; Evans method was conducted and is consistent with an $S=2$ ground state for 1 and 2 ( $\mu_{\text {eff }}=5.31$ and 5.79). Both acetates in 1 are $\kappa-2$ and Tbim is bound through the two benzimidazole arms that form six-membered chelate rings; the third benzimidazole arm, if bound to the metal, would give a seven-membered ring. Salt metatheses with $\mathrm{NaBPh}_{4} \mathbf{1}$ or $\mathbf{2}$ were performed in $\mathrm{MeOH}$ in an attempt to remove a single acetato or chlorido ligand and coordinate the third benzimidazole arm to iron. However, the reaction produced a yellow precipitate from which we obtained colorless crystals of the formulation $\left[\mathrm{Fe}\left\{\mathrm{Tbim}_{2}\right\}_{2}\left[\mathrm{BPh}_{4}\right]_{2} \quad\left([3]\left[\mathrm{BPh}_{4}\right]_{2}\right)\right.$, which is a bis-ligated metal complex salt whose connectivity was confirmed through XRD (Figure S16). 

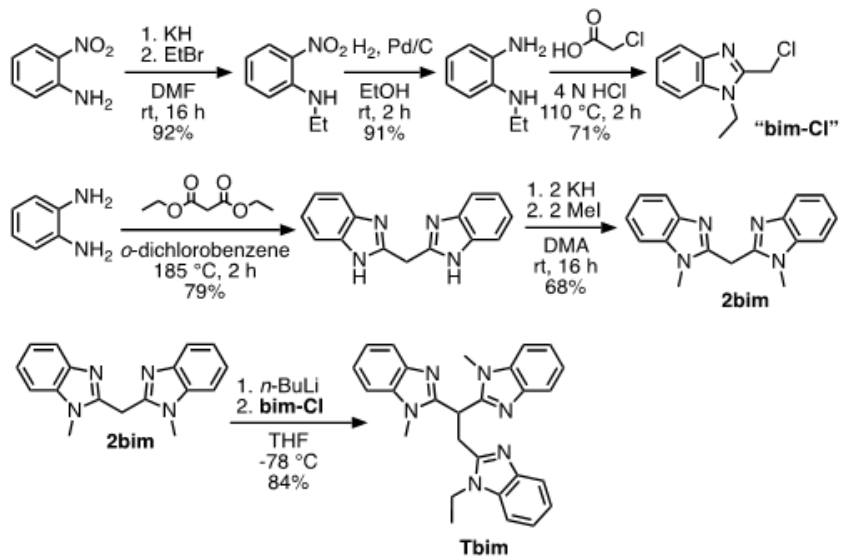

Scheme 1. Ligand synthesis.

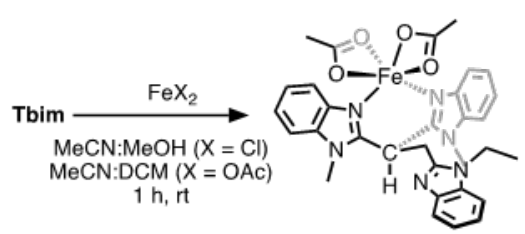

when $\mathrm{X}=\mathrm{OAC}$ $(84 \%)$

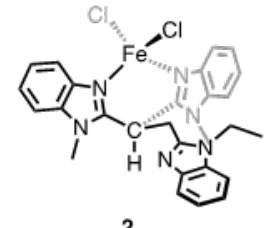

when $\mathrm{X}=\mathrm{Cl}$ $(61 \%)$
Scheme 2. Synthesis of 1 and 2.
$\mathrm{Tbim}+\mathrm{Fe}(\mathrm{OTf})_{2} \cdot 2 \mathrm{MeCN}$

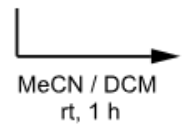
$1 \mathrm{~h}$

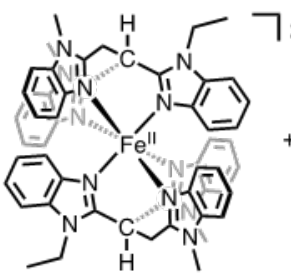

$[3]^{2+}$

$(56 \%)$

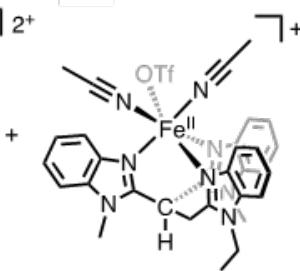

$[4]^{+}$ (inseparable from $[3]^{2+}$
Scheme 3. Synthesis of $[3]^{2+}$ and $[4]^{+}$

A reaction of Tbim with $\mathrm{Fe}(\mathrm{OTf})_{2} \cdot 2 \mathrm{MeCN}$ in acetonitrile also produced the bis-ligated metal complex [3][OTf]2. However, if a different workup procedure was used for the same in situ prepared 1:1 ligand:metal mixture, a different product was obtained. Namely, if the acetonitrile reaction mixture was removed in vacuo to near dryness and the resulting residue dissolved in dichloromethane the mono-ligated metal complex $\left[\mathrm{Fe}\{\mathrm{Tbim}\}(\mathrm{MeCN})_{2}(\mathrm{OTf})\right][\mathrm{OTf}] \quad([4][\mathrm{OTf}])$ was obtained in moderate yields. The presence of acetonitrile ligands is confirmed from ATR-FTIR spectroscopy ( $v \mathrm{CN}=2279$ and $\left.2285 \mathrm{~cm}^{-1}\right)$ and Xray crystallography (Figure 2). Owing to a Schlenk equilibrium between the two complexes and free $\mathrm{Fe}(\mathrm{OTf})_{2}$, [4][OTf] was inseparable from [3][OTf] $]_{2}$ under the conditions studied here.
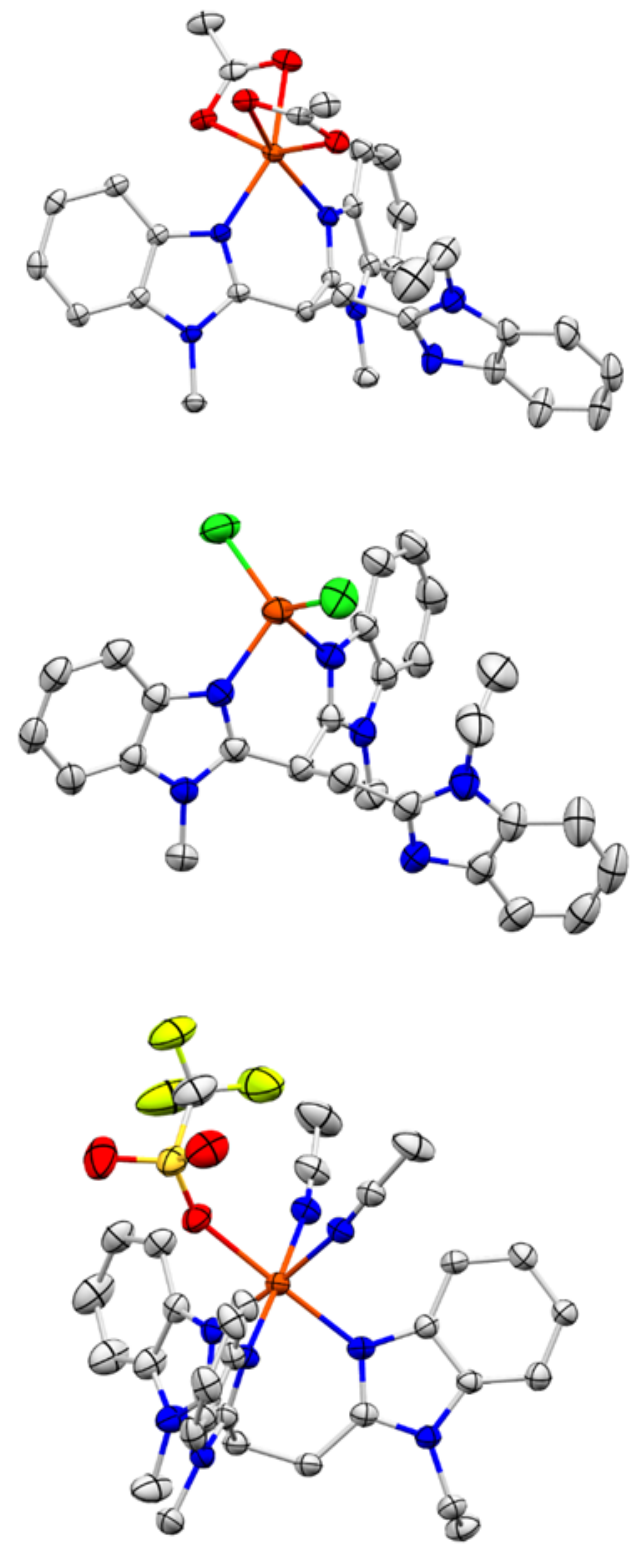

Figure 2. Molecular structure of (top to bottom) 1,2 and $[4]^{+}$with ellipsoids shown at $50 \%$ probability; $\mathrm{H}$-atoms, counterions, and solvent molecules are not shown. Color scheme: orange $=\mathrm{Fe}$; blue $=\mathrm{N}$; red $=\mathrm{O}$; yellow/green $=\mathrm{F} ;$ yellow $=\mathrm{S}$; green $=\mathrm{Cl}$; grey $=\mathrm{C}$.

A 1:1 reaction mixture of Tbim with $\mathrm{Fe}(\mathrm{OTf})_{2} \cdot 2 \mathrm{MeCN}$ in acetonitrile followed by ${ }^{1} \mathrm{H}$ NMR and ${ }^{19} \mathrm{~F}\left\{{ }^{1} \mathrm{H}\right\}$ NMR indicated the presence of both the mono-ligated and the bis-ligated complex in solution (Figure $\mathrm{S} 15$ ). The ${ }^{19} \mathrm{~F}\left\{{ }^{1} \mathrm{H}\right\}$ NMR spectrum of a $2: 1$ ligand:metal ratio contains a sharp peak at $-80 \mathrm{ppm}$ consistent with an unbound triflate ion for $[3][\mathrm{OTF}]_{2}{ }^{20}$ In contrast, when the ratio is less than $2: 1$, a broad signal is apparent at $-73 \mathrm{ppm}$ indicative of an equilibrium between bound and unbound triflate ions in solution implicating the presence of mono- ligated species $[4]^{+}$(Figure S12). This is consistent with a Schlenk equilibrium between $[3]^{2+}$ and $[4]^{+}$at room temperature in $\mathrm{MeCN}$; using density functional theory (DFT), the calculated equilibrium lies toward the bis ligated complex with a free energy of $-3.2 \mathrm{kcal} / \mathrm{mol}$ (see SI). ${ }^{1} \mathrm{H}$ NMR spectroscopy was used to construct a kind of "Job plot" to determine the optimal ratio of $\mathrm{Fe}(\mathrm{OTf})_{2}$ :Tbim to 
prepare in situ [4] $]^{+}$for the catalysis studies later (Figure S17), the optimal ratio to achieve the highest concentration of $[4]^{+}$in the 10 $\mathrm{mM}$ regime was found to be 3:2.
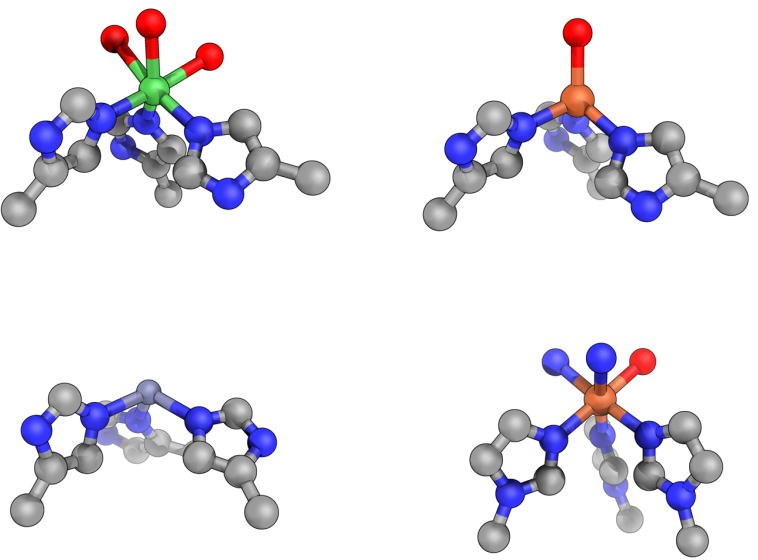

Figure 3. Simplified primary coordination spheres of three-histidine iron enzymes and $[4]^{+}$. Clockwise from top left: PDB 2atf, ${ }^{29}$ PDB $2 b 5 h,{ }^{30}[4]^{+}$, PDB 3bal. ${ }^{31}$ Color scheme: grey $=\mathrm{C}$; blue $=\mathrm{N}$; red $=\mathrm{O}$; orange $=\mathrm{Fe}$; green $=\mathrm{Ni}$; blue-grey $=\mathrm{Zn}$

In nature, $\mathrm{Fe}(\mathrm{II})$ centers coordinated by the three-histidine facial triad nominally occupy the face of a pseudo octahedron similar to the coordination observed in $[4]^{+}$(Figure 3 ). However, there are some notable differences between $[4]^{+}$and enzymatic coordination. The average benzimidazole $\mathrm{Fe}-\mathrm{N}$ distance of $[4]^{+}$is $2.15 \AA$ (average distance for all Fe-N/O bonds in $[4]^{+}$is $2.16 \AA$ ), whereas the average $\mathrm{Fe}-\mathrm{N} / \mathrm{O}$ distance in resting state mammalian cysteine dioxygenase (CDO) determined through $\mathrm{K}$ edge EXAFS is $2.04 \AA .{ }^{32}$ Additionally, the protein structures' $\mathrm{N}$ $\mathrm{M}-\mathrm{N}$ angles are about $100^{\circ}$ (average angle $95.7^{\circ}$ for 2atf, $100.6^{\circ}$ for $2 \mathrm{~b} 5 \mathrm{~h}$, and $102.4^{\circ}$ for $3 \mathrm{bal}$ ), whereas [4] $]^{+}$has an average $\mathrm{N}-$ $\mathrm{Fe}-\mathrm{N}$ angle of $89.9^{\circ}$ for the benzimidazole nitrogen atoms. Also, it is to be noted that, unlike the binding mode in Tbim and other synthetic ligands (e.g., Tp), the protein active site imidazoles twist into a paddle wheel conformation.

Following from the structural comparison of $[4]^{+}$with $3-\mathrm{His}$ coordination at enzyme active sites, we next tested $[4]^{+}$in biomimetic oxidation reactions and chose the substrate lithium diethyl 2-phenylmalonate (Li[Phmal], or Li[a]), model substrate often used in biomimicry of the 3-His enzyme diketone dioxygenase (Dke1). ${ }^{15,33}$ The use of Li[a] in Dke1 model studies is common because the natural substrate acac is difficult to oxidize; even Dke1 has a sluggish $k_{\mathrm{cat}}=6.5 \mathrm{~s}^{-1}$ for acac oxidation. ${ }^{34}$ The expected product distribution for aerobic oxidation of diethyl 2-phenylmalonate $(\mathrm{H}$-a) has been studied using a system with $\mathrm{O}_{2}$ and electrochemically generated superoxide. ${ }^{35}$ These products are ethylbenzoylformate (b) and HOPhmal (c) and their relative distribution depends on the concentration of substrate owing to competing reaction paths from a common alkylperoxo intermediate.

Catalytic oxidation studies were performed by treating a solution of $\mathrm{Li}[\mathrm{a}]$ and $5 \mathrm{~mol} \%$ catalyst with bubbling $\mathrm{O}_{2}$ for 1 hour (Scheme 4). After an aqueous work-up (see SI) the products were analyzed by GCMS and compared against authentic samples (Figure S20-S24). Under the conditions we used, $\mathrm{H}$-a was obtained as the major final product when no catalyst was present.
For runs that contained a catalyst a mixture of both $\mathbf{b}$ and $\mathbf{c}$ were obtained (Table 1); if water was not rigorously excluded, c was obtained as the major product. ${ }^{36}$ When the iron triflate control oxidation contained the oxygen radical scavenger diphenylamine, ${ }^{37} \mathrm{H}$-a was obtained as the major product accompanied by a small amount of $\mathbf{c}$ indicating that radical oxygen species are responsible for the oxidation. However, $\mathrm{KO}_{2}$ (either with or without $\mathrm{O}_{2}$ ) did not oxidize $\mathrm{Li}[\mathrm{a}]$ under the parent conditions we used (Scheme 4).

Scheme 4. Catalytic 1,3-Diester Oxidation Studies.

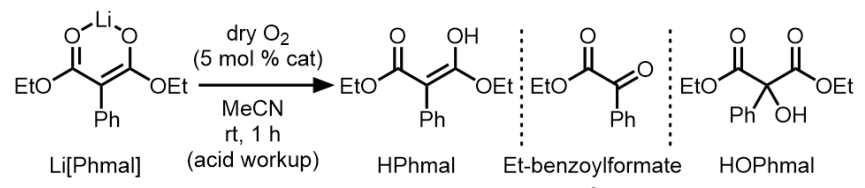

$\mathrm{Li}[\mathbf{a}]$

$(\mathrm{H}-\mathrm{a})$

(b)

Table 1. Results from catalytic aerobic oxidation of lithium diethyl 2phenylmalonate (Li[Phmal] $){ }^{[a]}$

\begin{tabular}{|c|c|c|c|}
\hline $\operatorname{cat}^{[\mathrm{b}]}$ & $\mathrm{H}-\mathbf{a}(\%)$ & b $(\%)$ & c $(\%)$ \\
\hline Fe/Tbim (3:2); "[4] $]^{+”}$ & 0 & 22 & 41 \\
\hline Fe/Tbim(1:4); “[3] & 0 & 17 & 51 \\
\hline $\mathrm{Fe}$ & 0 & 16 & 41 \\
\hline $\mathbf{F e}+\mathrm{Ph}_{2} \mathrm{NH}$ & 61 & 0 & 17 \\
\hline no iron or ligand & 77 & 0 & 4 \\
\hline
\end{tabular}

[a] Conditions: Substrate added dropwise, $5 \mathrm{~mol} \%$ catalyst, dry $\mathrm{O}_{2}, 1 \mathrm{~h}$; data reported average of two runs, see SI for full data. [b] $\mathbf{F e}=\mathrm{Fe}(\mathrm{OTf})_{2} \cdot 2 \mathrm{MeCN}$; $\mathrm{Fe} / \mathrm{L}$ represents that complex was prepared in situ.

In conclusion, we synthesized the biomimetic ligand Tbim and prepared coordination complexes with iron that structurally mimics the 3-His active site in nonheme iron enzymes, such as Dke1. We also demonstrated catalytic oxidation chemistry using the substrate $\mathrm{Li}[\mathrm{a}]$, but the simple salt $\mathrm{Fe}(\mathrm{OTf})_{2}$ had comparable performance and so the role of ligand was not inferred. Therefore, despite the common use of $\mathrm{Li}[\mathrm{a}]$, it is not advisable for biomimetic studies where it could give a "false positive" of ligand-induced biomimicry. Novel ligand platforms are still required to achieve the selectivity and rates achieved in enzymes. In particular, designing systems that do not form bis-ligated complexes and can oxidize difficult substrates like acac are required and are ongoing.

\section{Acknowledgements}

Financial support was provided by the University at Buffalo (UB). This work was completed using the resources of the Chemistry Instrument Center $(\mathrm{CIC})$ and Center for Computational Research (CCR) at UB.

Keywords: nonheme iron $\cdot$ coordination chemistry $\bullet$ oxygenase 
1. Bruijnincx, P. C. A.; Van Koten, G.; Gebbink, R. J. M. K. Chem. Soc. Rev. 2008, 37, 2716-2744.

2. Koehntop, K. D.; Emerson, J. P.; Que, L. J. Biol. Inorg. Chem. 2005, 10, 87-93.

3. Buongiorno, D.; Straganz, G. D. Coord. Chem. Rev. 2013 257, 541-563.

4. Blakesley, D. W.; Payne, S. C.; Hagen, K. S. Inorg. Chem. 2000, 39, 1979-1989.

5. Anandababu, K.; Ramasubramanian, R.; Wadepohl, H.; Comba, P.; Britto, N. J.; Jaccob, M.; Mayilmurugan, R. Chem. Eur. J. 2019, 25, 9540-9547.

6. Sallmann, M.; Limberg, C. Acc. Chem. Res. 2015, 48, 2734-2743.

7. Reger, D. L.; Little, C. A.; Rheingold, A. L.; Sommer, R.; Long, G. J. Inorganica Chim. Acta, 2001, 316, 65-70.

8. Tazelaar, C. G. J.; Slootweg, J. C.; Lammertsma, K. Coord. Chem. Rev. 2018, 356, 115-126.

9. Oddon, F.; Chiba, Y.; Nakazawa, J.; Ohta, T.; Ogura, T.; Hikichi, S. Angew. Chem., Int. Ed., 2015, 54, 7336-7339.

10. Fischer, A. A.; Lindeman S. V.; Fiedler, A. T. Chem. Commun. 2018, 54, 11344.

11. Gordon, J. B.; Vilbert, A. C.; DiMucci, I. M.; MacMillan, S. N.; Lancaster, K. M.; Moëmme-Loccoz, P.; Goldberg, D. P. J. Am. Chem. Soc. 2019, 141, 17533-17547.

12. Kass, D.; Corona, T.; Warm, K.; Braun-cula, B.; Kuhlmann, U.; Bill, E.; Mebs, S.; Swart, M.; Dau, H.; Haumann, M.; Hildebrandt, P.; Ray, K. J. Am. Chem. Soc. 2020, 142, 5924-5928.

13. Chiang, C.W.; Kleepspies, S. T.; Stout, H. D; Meier, K. K.; Li, P.Y.; Bominaar, E. L.; Que, L.; Münk, E.; Lee, W.Z. J. Am. Chem. Soc. 2014, 136, 10846.

14. Blakely, M. N.; Dedushko, M. A.; Poon, P. C. Y.; VillarAcevedo, G.; Kovacs, J. A. J. Am. Chem. Soc. 2019, 141, 1867-1870.

15. Siewert, I.; Limberg, C. A. Angew. Chem. Int. Ed., 2008, 47, 7953-7956.

16. Debobrata, S.; Paine, T. K. Chem. Sci. 2016, 7, 5322 5331.

17. Sahu, S.; Goldberg, D. P. J. Am. Chem. Soc. 2016, 138 , 11410-11428.

18. Que, L.; Tolman, W. B. Nature 2008, 455, 333-340.

19. Bruijnincx, P. C. A.; Lutz, M.; Spek, A. L.; Hagen, W. R.; Weckhuysen, B. M.; Van Koten, G.; Gebbink, R. J. M. K. J. Am. Chem. Soc. 2007, 129, 2275-2286.
20. Bruijnincx, P. C. A.; Lutz, M.; Spek, A. L.; Van Faassen, E. E.; Weckhuysen, B. M.; Van Koten, G.; Klein Gebbink, R. J. M. Eur. J. Inorg. Chem. 2005, 4, 779-787.

21. Park, H.; Baus, J. S.; Lindeman, S. V.; Fiedler, A. T. Inorg Chem. 2011, 50, 11978-11989.

22. Moser, A.; Range, K.; York, D. M. J. Phys. Chem. B. 2010 , $114,13911-13921$.

23. The $\mathrm{pK}$ a of 1,2-dimethylbenzimidazole was measured as part of this work (see SI).

24. Martínez, C. H. R.; Dardonville, C. ACS Med. Chem. Lett. 2013, 4, 142-145.

25. Lenarcik., B.; Ojczenasz, P. J. Heterocyclic Chem. 2002, $39,287$.

26. Lacy, D. C. Inorg. Chem. Front. 2019, 6, 2396-2403.

27. Elgafi, S.; Field, L. D.; Messerle, B. A.; Turner, P.; Hambley, T. W. J. Organomet. Chem. 1999, 588, 69-77.

28. Sahay, I. I.; Ghalsasi, P. S. Synth. Commun. 2017, 47, 825-834.

26. J. G. McCoy, L. J. Bailey, E. Bitto, C. A. Bingman, D. J. Aceti, B. G. Fox, G. N. Phillips, Proc. Natl. Acad. Sci. U.S.A. 2006, 103, 3084-3089.

30. C. R. Simmons, Q. Huang, Q Hao, T. P. Begley, P. A. Karplus, M. H. Stipanuk. J. Biol. Chem. 2006, 281, 1872318733.

31. G. R. Stranzl, U. G. Wagner, G. Straganz, W. Steiner and C. Kratky, Protein Data Bank in Europe, https://www.ebi.ac.uk/pdbe/entry/pdb/3bal, (accessed June 2020), unpublished work.

32. Chai, S. C.; Bruyere, J. R.; Maroney, M. J. J. Biol. Chem. 2006, 281, 15774-15779.

33. (a) Allpress, C. J.; Grubel, K.; Szajna-Fuller, E.; Arif, A. M.; Berreau, L. M. J. Am. Chem. Soc. 2013, 135, 659-668. (b) Park, H.; Bittner, M. M.; Baus, J. S.; Lindeman, S. V.; Fiedler, A. T. Inorg. Chem. 2013, 135, 659-668. (c) Ramasubramanian, R.; Anandababu, K.; Kumar, M.; Mayilmurugan, R. Dalton Tran. 2018, 47, 4049-4053.

34. Straganz, G. D.; Nidetzky, B. J. Am. Chem. Soc. 2005, 127, 12306-12314

35. Allen, P. M.; Hess, U.; Foote, C. S.; Baizer, M. M. Synthetic Communications 1982, 12, 123-129.

36. See SI for drying procedure.

37. Comba, P.; Lee, Y.M.; Nam, W.; Waleska, A. Chem. Commun. 2014, 50, 412. 


\section{Entry for the Table of Contents}

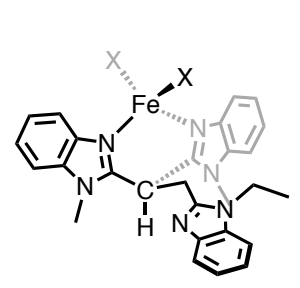

$1(X=O A c), 2(X=C l)$

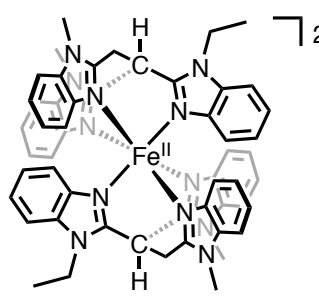

$[3]^{2+}$

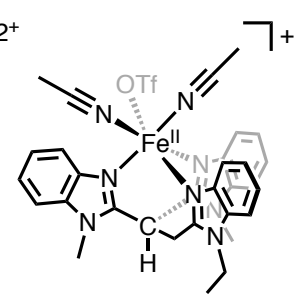

$[4]^{+}$

A new tripodal tris-benzimidazole ligand (Tbim) that structurally mimics the 3-His coordination environment of nonheme mononuclear iron oxygenases was prepared and coordinated to iron and revealed diverse coordination chemistry. The aerobic oxidation of biomimetic model substrate diethyl-2-phenylmalonate was studied using the Tbim-Fe and $\mathrm{Fe}(\mathrm{OTf})_{2}$.

Institute and/or researcher Twitter usernames: @LacyLab_UB 
A Facially Coordinating Tris-Benzimidazole Ligand for Nonheme Iron Enzyme Models

Parami S. Gunasekera, ${ }^{\dagger}$ Preshit C. Abhyankar, ${ }^{\dagger}$ Samantha N. MacMillan, ${ }^{\S}$ David C. Lacy ${ }^{* \dagger}$

t Department of Chemistry, University at Buffalo, State University of New York, Buffalo, New York 1426o, United States.

$\S$ Department of Chemistry and Chemical Biology, Cornell University, Ithaca, New York 14853, United States

E-mail: DCLacy@buffalo.edu

Contents

Page

General considerations

S2

Crystallographic methods

S2

Computational methods

S2

Synthesis and characterization of $\mathbf{2 b i m}$

S2

Synthesis and characterization of Tbim

S3

Figure S1: ${ }^{1} \mathrm{H}$ NMR spectrum of Tbim in $\mathrm{MeCN}-d_{3}{ }^{*}$

$\mathrm{S} 3$

Figure S2: ${ }^{13} \mathrm{C}$ NMR spectrum of Tbim in chloroform- $d^{*} \quad$ S3

Figure S3: ATR-FTIR spectrum of Tbim

Synthesis and characterization of $\mathbf{1}$

Figure S4: ${ }^{1} \mathrm{H}$ NMR spectrum of $\mathbf{1}$ in $\mathrm{MeCN}-d_{3}{ }^{*}$

Figure S5: ATR-FTIR spectrum of 1

Synthetic details and characterization for 2

Figure S6: ${ }^{1} \mathrm{H}$ NMR spectrum of 2 in $\mathrm{MeOH}-d_{4}{ }^{*}$

Figure S7: ATR-FTIR spectrum of 2

Synthesis and characterization of $[\mathbf{3}]\left[\mathrm{BPh}_{4}\right]_{2}$

Figure S8: ${ }^{1} \mathrm{H}$ NMR spectrum of $[3]\left[\mathrm{BPh}_{4}\right]_{2}$ in DMSO- $d_{6}$

Figure S9: ATR-FTIR spectrum of $[3]\left[\mathrm{BPh}_{4}\right]_{2}$

Synthesis and characterization of [3][OTf $]_{2}$ and [4][OTf]

Figure S10: ${ }^{1} \mathrm{H}$ NMR spectrum of [3][OTf $]_{2}$ in $\mathrm{MeCN}-d_{3}{ }^{*}$

Figure S11: ${ }^{19} \mathrm{~F}\left\{{ }^{1} \mathrm{H}\right\}$ NMR spectrum of [3][OTf $]_{2}$ in $\mathrm{MeCN}-d_{3}$

$\mathrm{S} 4$

$\mathrm{S} 4$

$\mathrm{S}_{5}$

S5

S5

S6

S6

S6

S7

S7

S7

S8

S8

Figure S13: ATR-FTIR spectrum of [3][OTf $]_{2}$

S9

Figure S14: ATR-FTIR spectrum of [4][OTf] with MeCN stretches

S9

Figure S15: ${ }^{1} \mathrm{H}$ NMR spectrum of a mixture of [3][OTf] $]_{2}$ and [4][OTf] in $\mathrm{MeCN}-d_{3}{ }^{*} \quad$ S10

Figures S16. XRD determined connectivity structure of [3] ${ }^{2+}$

Procedure for determining Fe(II):Tbim mole ratio

S10

Figure S17: Plot of optimal mole ratio for in situ preparation of [4] ${ }^{+}$

S11

Procedure for $\mathrm{p} K_{\mathrm{a}}$ measurements

S11

Figure S18: Spectra and plots used for $\mathrm{p} K_{\mathrm{a}}$ measurements

$\mathrm{S} 12$

Table S1: $\mathrm{p} K_{\mathrm{a}}$ table for Figure $\mathrm{S} 19$

Figures S19: Comparison of ligand conjugate acid $\mathrm{p} K_{\mathrm{a}}$ to histidine

S12

Procedures for catalytic oxidation of LiPhmal

Table S2. oxidation of Li[Phmal] results.

$\mathrm{S} 13$

S14

Figure S20: GC trace for HPhmal and its oxidation products

S14

Characterization data for oxidation products

Determination of Schlenk equilibrium from DFT

S14

Table S3: DFT computed Gibbs's free energies for Schlenk equilibrium S15-S16

References S17

$\mathrm{S} 17$

S17-S18 


\section{EXPERIMENTAL}

\section{General considerations}

All chemicals were used as purchased from chemical vendors unless otherwise noted. Manipulations of air sensitive compounds were carried out in a nitrogen filled Genesis VAC glovebox or using Schlenk techniques to ensure dry and oxygen-free conditions. Dry, oxygen-free solvents were obtained from a PPT solvent purification system and were purified and stored over $3 \AA$ molecular sieves. The acetonitrile used for catalysis was further dried by passing through alumina and stored over $3 \AA$ molecular sieves. The sieves were activated at $200^{\circ} \mathrm{C}$ under vacuum for 48 hours prior to use. NMR experiments were carried out on Varian Mercury $300 \mathrm{MHz}$ or Inova 400 MHz spectrometers. ATR-FTIR spectra were collected using a Bruker Alpha IR spectrometer with the "ATR Platinum" insert adapter (diamond crystal), which was stored inside a nitrogen filled VAC Atmospheres glovebox. UV-vis spectra were collected using an 8154 Agilent Spectrophotometer. The $\mathrm{pH}$ of the buffer solutions was measured with Mettler Toledo FiveEasy $\mathrm{pH}$ meter and a Mettler Toledo glass electrode lE438-IP67 at $25{ }^{\circ} \mathrm{C}$. HRMS was performed using a FT-ICR Brucker $12 \mathrm{~T}$ mass spectrometer. GC-MS analysis was performed with a HP 5890 Series II GC containing a J\&W Scientific, Inc. column $(30 \mathrm{~m} \times 0.250 \mathrm{~mm})$ with a $0.10 \mu \mathrm{m}$ thin film of phenyl arylene polymer coupled to a HP 5972 Series mass selective detector. Volumetric measurements were carried in analytic grade glassware. All aqueous solutions were prepared using distilled, deionized water. CHN combustion analysis was performed by Robertson Microlit Laboratories, NJ USA. Fe(OTf $)_{2} \cdot 2 \mathrm{MeCN},{ }^{1}$ bis(benzimidazole-2-yl)methane, ${ }^{2}$ 2-chloromethyl-1-ethylbenzimidazole, ${ }^{3}$ Li[Phmal], ${ }^{4}$ ethyl benzoylformate, ${ }^{5}$ sodium thiocresol, ${ }^{6} p$-toluenesulfinic acid,7 S-(4-methylphenyl) 4-methylbenzenesulfonothioate ${ }^{8}$ and 1,2-di- $p$ tolyldisulfane ${ }^{9}$ were prepared according to literature procedures.

\section{Crystallographic methods}

Low-temperature X-ray diffraction data for [Fe $\{$ Tbim $\left.\}(\mathrm{MeCN})_{2}(\mathrm{OTf})\right][\mathrm{OTf}]$ (Rlacy28), $\left[\mathrm{Fe}\{\mathbf{T b i m}\}(\mathrm{OAc})_{2}\right]$ (Rlacy31) and [Fe $\{$ Tbim $\left.\}(\mathrm{Cl})_{2}\right]$ (Rlacy37) were collected on a Rigaku XtaLAB Synergy diffractometer coupled to a Rigaku. Rlacy28 was treated as a racemic twin; the explicit refinement of the Flack parameter yielded a value of $0.450(4)$. Hypix detector with $\mathrm{Cu} \mathrm{Ka}$ radiation $(\lambda=1.54184 \AA$ ) from a PhotonJet micro-focus X-ray source at $100 \mathrm{~K}$ for Rlacy28 and Rlacy37 and $253 \mathrm{~K}$ for Rlacy31. The diffraction images were processed and scaled using the CrysAlisPro software. ${ }^{10}$ The structures were solved through intrinsic phasing using SHELXT ${ }^{11}$ and refined against $\mathrm{F}^{2}$ on all data by full-matrix least squares with SHELXL ${ }^{12}$ following established refinement strategies. ${ }^{13}$ All non-hydrogen atoms were refined anisotropically. All hydrogen atoms were included in the model at geometrically calculated positions and refined using a riding model. The isotropic displacement parameters of all hydrogen atoms were fixed to 1.2 times the $\mathrm{U}_{\text {eq }}$ value of the atoms they are linked to (1.5 times for methyl groups).

\section{Computational methods}

All DFT calculations were performed in ORCA $4.0^{14}$ using the B3LYP functional with atom-pairwise dispersion correction with Becke-Johnson damping ${ }^{15,16}$ and def2-SVP ${ }^{17}$ basis set. The conductor-like polarizable continuum model (C-PCM) implicit solvation model was used to incorporate solvent effects. All thermochemical calculations were performed at standard conditions ( $1 \mathrm{~atm}$ pressure and $298.15 \mathrm{~K}$ ). The optimized gas-phase geometries of all molecules were computed and minima were confirmed by the absence of imaginary frequencies. Optimized geometries of $\mathrm{MeCN}$, [OTf]-, $\left[\mathrm{Fe}(\mathrm{MeCN})_{4}(\mathrm{OTf})_{2}\right]$, and the free ligand (Tbim) solvated in MeCN were obtained similarly. The single point energies of $\left[\mathrm{Fe}(\mathrm{Tbim})(\mathrm{MeCN})_{2}(\mathrm{OTf})\right]^{-}$and $[\mathrm{Fe}(\mathrm{Tbim})]^{2+}$ solvated in $\mathrm{MeCN}$ were obtained using the cartesian coordinates of the gas-phase optimized molecules. These single point energies were utilized to calculate their solvation Gibb’s free enthalpies.

\section{Synthesis}

Synthesis of Bis(1-methylbenzimidazol-2-yl)methane (2bim): In a glovebox, a $500 \mathrm{~mL}$ Schlenk flask equipped with a stir bar was charged with bis(benzimidazole-2-yl)methane (2.73 g, $11.0 \mathrm{mmol})$ and dissolved in $150 \mathrm{~mL}$ of dry DMA. The solution was stirred for 10 minutes. Careful addition of $\mathrm{KH}$ (0.972 g, $24.2 \mathrm{mmol})$ to the solution (CAREFUL: slow addition necessary,) over fifteen minutes caused the solution to turn red and the solution was stirred for an additional 30 minutes after which effervescence ceased. The flask was removed from the glovebox and blanketed with argon on a Schlenk line. Methyl iodide $(1.25 \mathrm{~mL}, 24.6 \mathrm{mmol})$ was added dropwise to the reaction mixture (by hand with a syringe, $\approx 3$ minutes) and the solution was stirred overnight at room temperature. Open to air, the reaction mixture was poured into $300 \mathrm{~mL}$ of rapidly stirring water and the resulting solid was filtered, washed with $50 \mathrm{~mL}$ of water and dried under vacuum (2.05 g, 68\% yield). ${ }^{1} \mathrm{H}$ NMR data matches with the literature reported values. ${ }^{2}{ }^{1} \mathrm{H}$ NMR (Chloroform- $d$, $\left.300 \mathrm{MHz}\right): \delta 3.88\left(\mathrm{~s}, 6 \mathrm{H}, \mathrm{CH}_{3}\right), 4.67\left(\mathrm{~s}, 2 \mathrm{H}, \mathrm{CH}_{2}\right)$, 7.25 (m, 6H, aromatic), 7.71 (m, $2 \mathrm{H}$, aromatic).

Synthesis of 2,2'-(2-(1-ethylbenzimidazol-2yl)ethane-1,1-diyl)bis(1-methylbenzimidazole) (Tbim): In a glovebox, a $100 \mathrm{~mL}$ Schlenk tube equipped with a stir bar was charged with $\mathbf{2 b i m}(0.858 \mathrm{~g}, 3.11 \mathrm{mmol}$ ) to which $20 \mathrm{~mL}$ of dry THF was added. The flask was removed from the glovebox and blanketed with argon on a Schlenk line. The solution was cooled to $-78^{\circ} \mathrm{C}$, after which $n$-butyllithium (1.37 mL, $3.46 \mathrm{mmol}, 2.5 \mathrm{M}$ in hexane) was added to the solution via a syringe and the reaction mixture was stirred for 1 hour (color change from brown to yellow brown). In a glovebox, 2-chloromethyl 1-ethylbenzimidazole (0.587 g, $3.02 \mathrm{mmol}$ ) charged in a Schlenk 
flask was dissolved in $20 \mathrm{~mL}$ of dry THF and stirred for 10 minutes. The solution was taken out of the glovebox and under Schlenk conditions the solution was added dropwise to the reaction mixture containing 2 bim and $n$ butyllithium via cannula transfer. The reaction vessel was left in the cold bath overnight to slowly warm to room temperature with stirring. The reaction mixture was opened to air and quenched with $10 \mathrm{~mL}$ of water, volatiles were removed, and the aqueous layer was extracted with ethyl acetate $(3 \times 30 \mathrm{~mL})$. The organic layer was dried over anhydrous $\mathrm{Na}_{2} \mathrm{SO}_{4}$ and filtered. The filtrate was evaporated to obtain a yellow orange solid, which was further purified by washing with diethyl either $(10 \mathrm{~mL})$ and then hexane $(10 \mathrm{~mL})$, and repeating this process two more times. The ligand was obtained as a solid that was purified by column chromatography [ethyl acetate/methanol/ammonium hydroxide (80:19:1)]. Batches varied in color from off white, light pink, to faint yellow (1.14 g, 84\% yield). ${ }^{1} \mathrm{H}$ NMR (MeCN- $\left.d_{3}, 300 \mathrm{MHz}\right): \delta 1.38\left(\mathrm{t}, \mathrm{J}=7.2 \mathrm{~Hz}, 3 \mathrm{H},-\mathrm{CH}_{3}\right), 3.75\left(\mathrm{~s}, 6 \mathrm{H}, \mathrm{NCH}_{3}\right)$, $4.04\left(\mathrm{~d}, \mathrm{~J}=7.2 \mathrm{~Hz}, 2 \mathrm{H},-\mathrm{CH}_{2}-\right.$ ), $4.3 \mathrm{O}\left(\mathrm{q}, \mathrm{J}=7.2 \mathrm{~Hz}, 2 \mathrm{H}, \mathrm{NCH}_{2}-\right), 5.74(\mathrm{t}, \mathrm{J}=7.2 \mathrm{~Hz}, 1 \mathrm{H},-\mathrm{HC}$ meso carbon), 7.17 (dd, $\mathrm{J}=13.7,7.5 \mathrm{~Hz}, 2 \mathrm{H}$, aromatic), 7.26 (d, $\mathrm{J}=7.1 \mathrm{~Hz}, 1 \mathrm{H}$, aromatic), 7.4 (d, $\mathrm{J}=9.2 \mathrm{~Hz}, 2 \mathrm{H}$, aromatic), 7.54 (dt, $\mathrm{J}=15.2,7.4 \mathrm{~Hz}, 3 \mathrm{H}$, aromatic). ${ }^{13} \mathrm{C}$ NMR (Chloroform- $d, 101 \mathrm{MHz}$ ): $\delta$ 15.13, 30.05, 36.33, 38.37, 109.34, 109.56, $118.97,119.92,122.22,122.30,134.71,136.02,142.38,142.55,151.85,152.34 . \mathrm{mp}: 205^{-} 208{ }^{\circ} \mathrm{C}^{2}$ ATR-FTIR (cm ${ }^{-}$ 1): 3052, 2969, 1614, 1457, 1270, 1006, 803, 749, 736, 556, 415. HRMS (LDI/FT-ICR) m/z: Calcd for [2(Tbim)+Na]+ 891.43356; Found. 891.43654, Calcd for [Tbim+H] ${ }^{+} 435.22972$; Found. 435.23023.

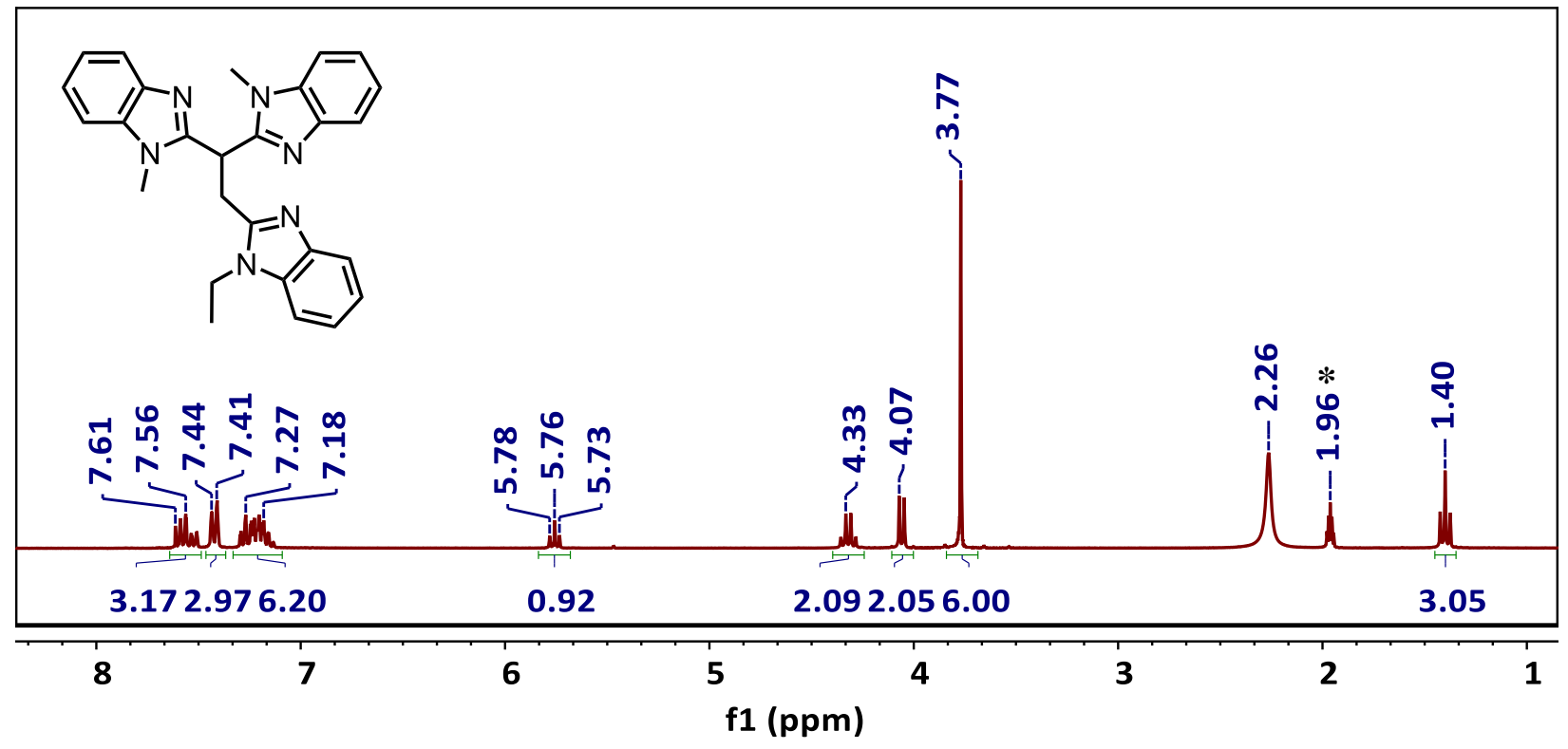

Figure S1: ${ }^{1} \mathrm{H} \mathrm{NMR}$ spectrum of Tbim in $\mathrm{MeCN}-\mathrm{d}_{3}{ }^{*}$

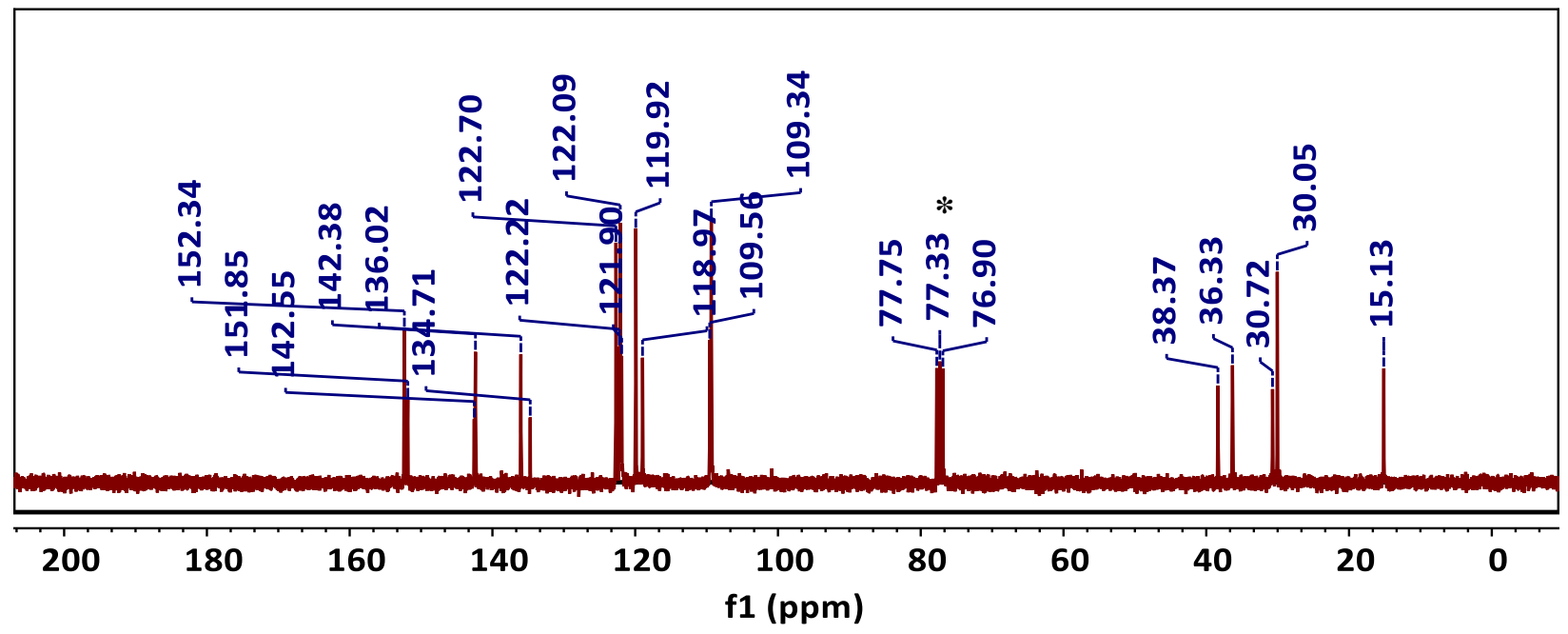

Figure S2: ${ }^{13} \mathrm{C}$ NMR spectrum of Tbim in chloroform- $d^{*}$ 


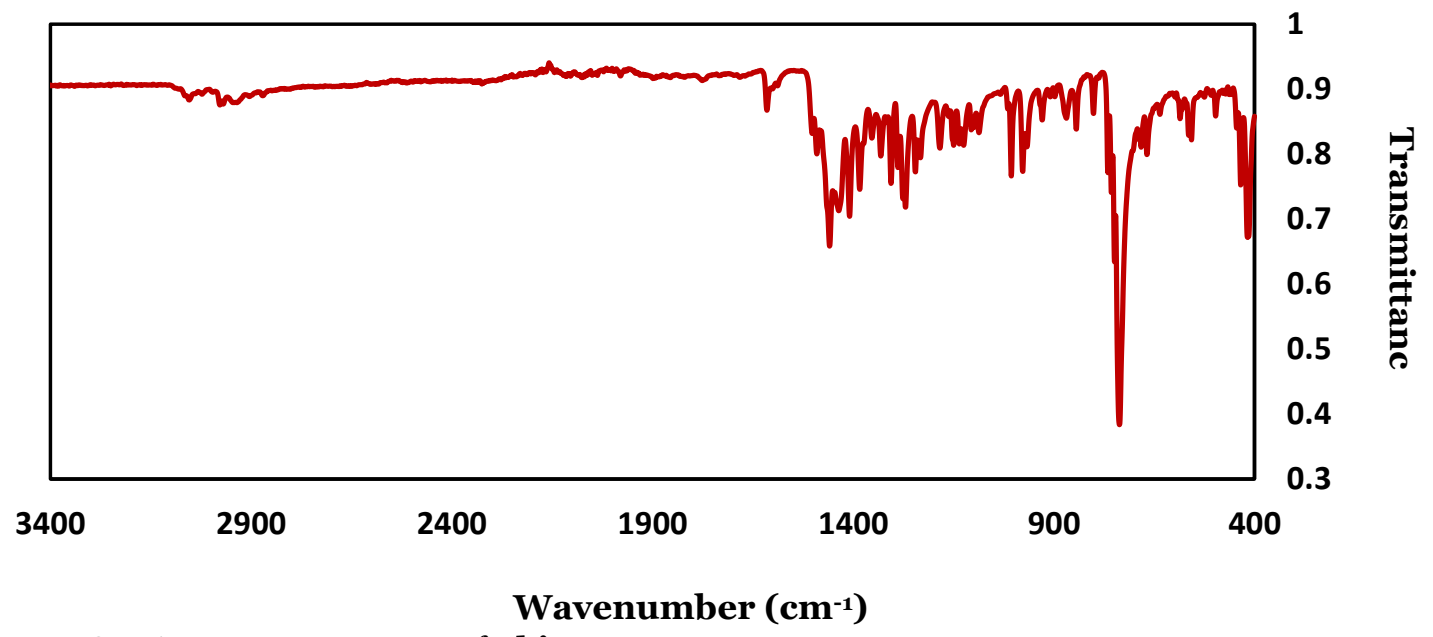

Figure S3: ATR-FTIR spectrum of Tbim 


\section{Synthesis and characterization of 1,2 , and 3}

[Fe $\{$ Tbim $\left.\}(\mathrm{OAc})_{2}\right]$ (1): $\mathrm{Fe}(\mathrm{OAc})_{2}(40 \mathrm{mg}, 0.23 \mathrm{mmol})$ and Tbim (100 mg, $0.230 \mathrm{mmol}$ ) was stirred in $15 \mathrm{~mL}$ of dry acetonitrile for 1 hour under nitrogen in a glovebox. The solution was removed in vacuo and dissolved in 10 $\mathrm{mL}$ of dry dichloromethane. Diffusion of diethyl ether into the reaction mixture gave yellow microcrystalline solids (118 mg, isolated yield: 84\%). Crystals suitable for XRD were obtained by layering a dichloromethane solution of 1 under diethyl ether. ATR-FTIR ( $\left.\mathrm{cm}^{-1}\right)$ : 2309, 2279, 1454, 1282, 1236, 1221, 1149, 1028, 748, 634, 1564, 1483, 1409, 1336, 1007, 734, 673. UV-vis (DCM, [ $\left.\left.\varepsilon \mathrm{M}^{-1} \mathrm{~cm}^{-1}\right]\right): \lambda_{\max }=209 \mathrm{~nm}(944) .{ }^{1} \mathrm{H}$ NMR $\left(\mathrm{MeCN}-d_{3}\right.$, $300 \mathrm{MHz}$ ): $\delta$-20.02, $-0.59,-0.20,1.59$, 3.60, 3.93, 4.20, 4.68, 5.62, 5.86, 6.93, 7.20, 7.36, 7.58, 7.77, 8.76, 21.48, 21.77, 88.30. Anal. Calcd (found) for 1•0.5 $\mathrm{CH}_{2} \mathrm{Cl}_{2}\left(\mathrm{C}_{31.5} \mathrm{H}_{32} \mathrm{ClFeN}_{6} \mathrm{O}_{4}\right)$ : C, 58.12 (58.36); H, 5.11 (5.16); N, 12.91 (13.05). Evans' method (MeCN- $\left.d_{3}, 300 \mathrm{MHz}, 298 \mathrm{~K}\right) \mu_{\text {eff }}=5.31 \mu_{\mathrm{B}}$.

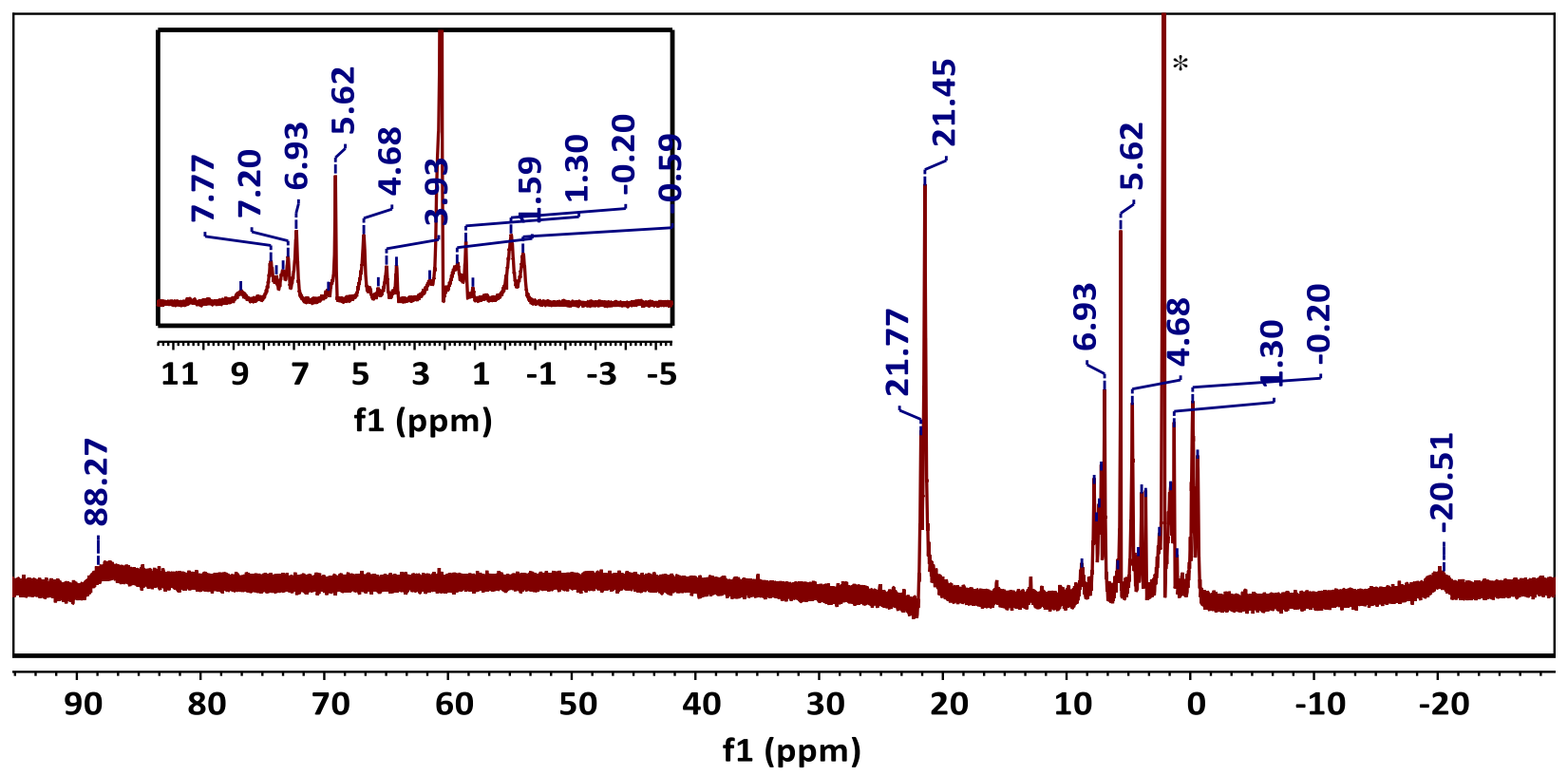

Figure S4: ${ }^{1} \mathrm{H}$ NMR spectrum of 1 in $\mathrm{MeCN}-d_{3}{ }^{*}$

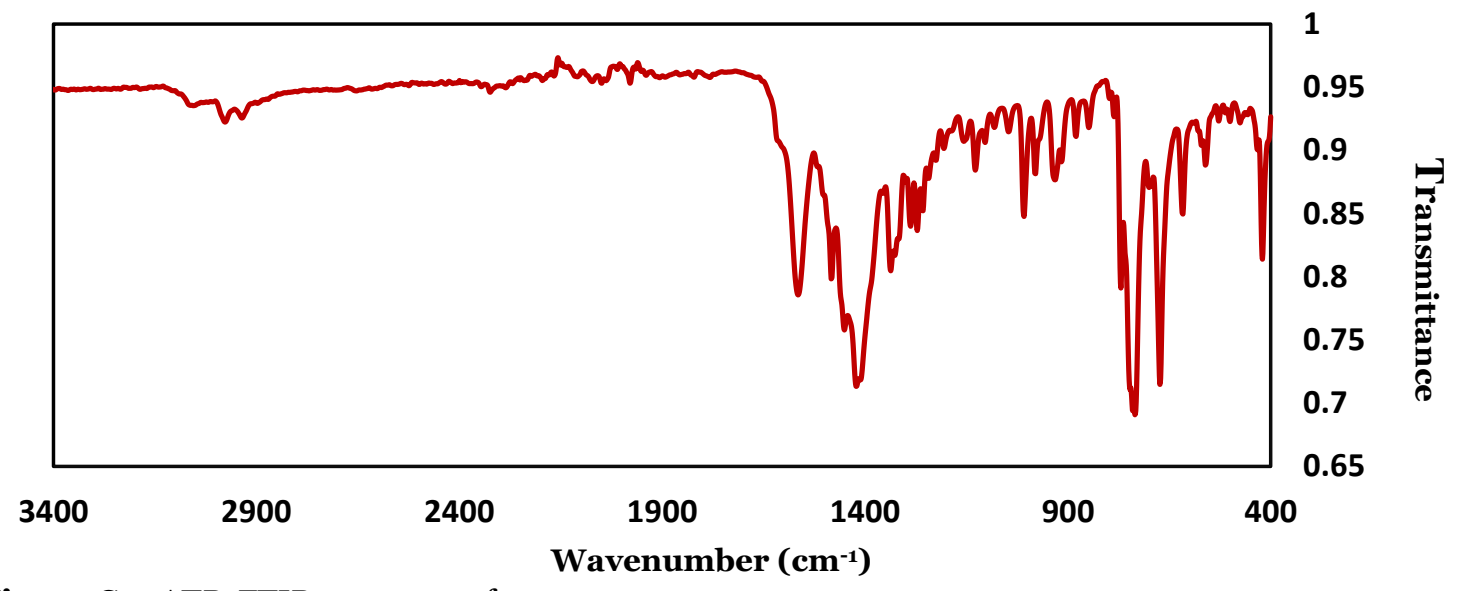

Figure S5: ATR-FTIR spectrum of 1 
[Fe $\{$ Tbim $\left.\}(C l)_{2}\right]$ (2): Anhydrous $\mathrm{FeCl}_{2}(12 \mathrm{mg}, 0.092 \mathrm{mmol})$ and Tbim (40 $\mathrm{mg}$, $0.092 \mathrm{mmol}$ ) were stirred together in $5 \mathrm{~mL}$ of dry acetonitrile in a nitrogen filled glovebox. The suspension was treated with methanol dropwise until a homogenous solution was obtained. The solution was further stirred for 1 hour and the resulting reaction mixture was filtered. Diffusion of diethyl ether to the reaction mixture produced colorless crystals of 2 (32 mg, 61\% yield). ATR-FTIR (cm-1): 3021, 2978, 1616, 1450, 1402, 1332, 1283, 1149, 1009, 739, 560. ${ }^{1} \mathrm{H}$ NMR $\left(\mathrm{MeOH}-d_{4}, 4 \mathrm{OO} \mathrm{MHz}\right): \delta$-0.54, $-0.32,1.14,4.61,5.94,6.67,8.13,8.91,9.61,9.74,10.22,11.54,11.75,12.30,12.75$, 23.66, 25.01, 27.50, 28.29. Anal. Calcd (found) for $2 \cdot 0.5 \mathrm{CH}_{2} \mathrm{Cl}_{2}\left(\mathrm{C}_{31.5} \mathrm{H}_{32} \mathrm{ClFeN}_{6} \mathrm{O}_{4}\right): \mathrm{C}, 58.12$ (58.36); H, 5.11 (5.16); N, 12.91 (13.05). HRMS (LDI/FT-ICR) m/z: Calcd for [(2)-Cl] ${ }^{+}$525.12569; Found 525.12707. Evans' method $\left(\mathrm{MeOH}-d_{4}, 300 \mathrm{MHz}, 298 \mathrm{~K}\right) \mu_{\mathrm{eff}}=5.79 \mu_{\mathrm{B}}$.

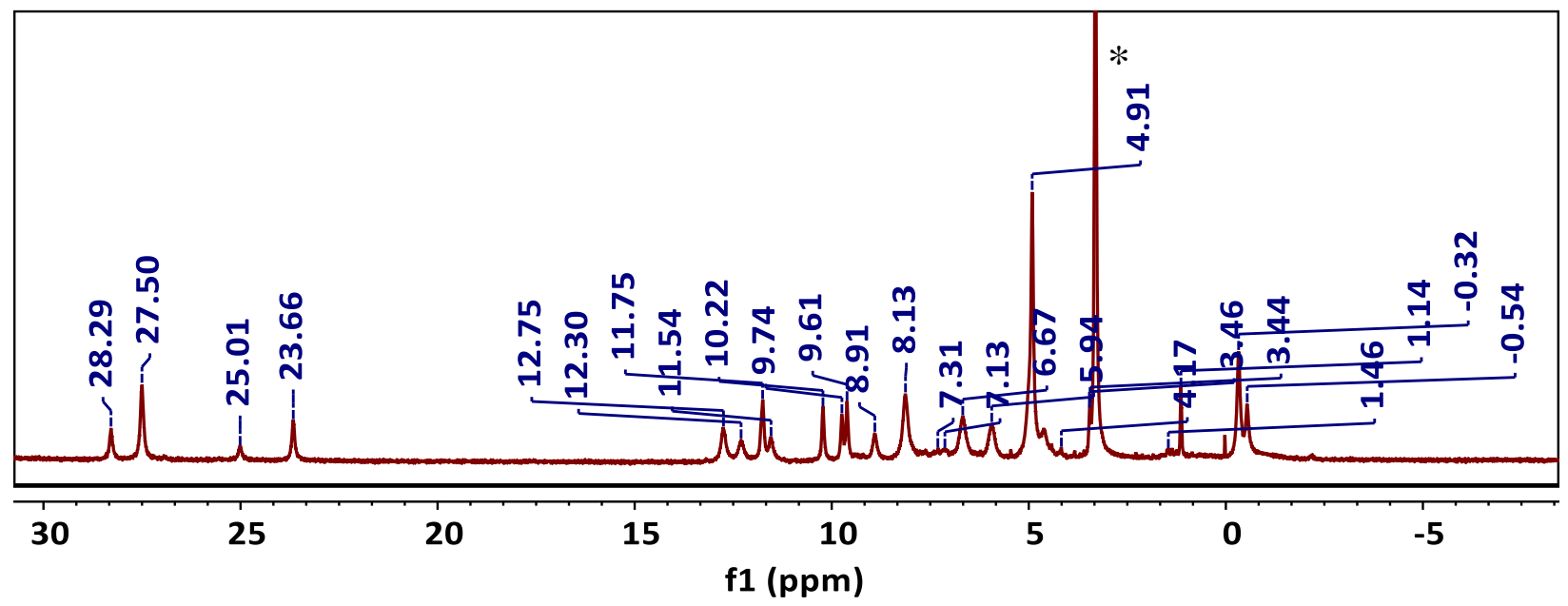

Figure S6: ${ }^{1} \mathrm{H}$ NMR spectrum of 2 in $\mathrm{MeOH}-d_{4}{ }^{*}$

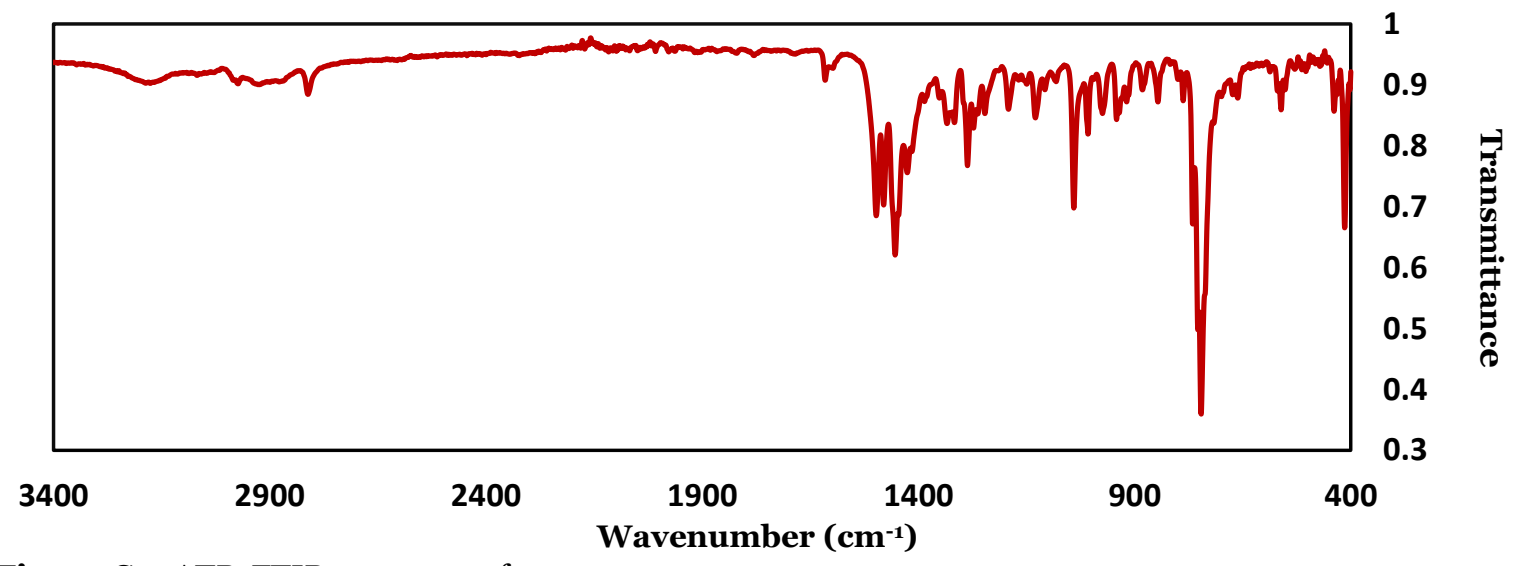

Figure S7: ATR-FTIR spectrum of 2 
$\left[\mathrm{Fe}\{\boldsymbol{T} \boldsymbol{T b i m}\}_{2}\right]\left[\mathrm{BPh}_{4}\right]_{2}\left([3][\mathrm{BPh}]_{4}\right): \mathrm{Fe}(\mathrm{OAc})_{2}(8 \mathrm{mg}, 0.05 \mathrm{mmol})$ and Tbim (20 $\left.\mathrm{mg}, 0.046 \mathrm{mmol}\right)$ were mixed together in $1 \mathrm{~mL}$ of acetonitrile for 30 minutes. Once the solution became homogenous, the solvent was removed in vacuo and the resulting residue was taken up in $5 \mathrm{~mL}$ of methanol. The solution was stirred with $\mathrm{NaBPh}_{4}(16$ $\mathrm{mg}, 0.046 \mathrm{mmol}$ ) and a yellow solid formed that was isolated by filtration and redissolved in a minimum amount of dichloromethane from which crystalline $[3]\left[\mathrm{BPh}_{4}\right]_{2}$ precipitated over 24 hours $(18.2 \mathrm{mg}, 98 \%$ yield). (Figure S16) ATR-FTIR (cm-1): 3052, 2978, 1477, 1448, 1264, 838, 730, 703, 610. ${ }^{1} \mathrm{H}$ NMR (DMSO- $\left.d_{6}, 400 \mathrm{MHz}\right): \delta$ $-43.39,-0.51,-0.04,1.76,2.07,2.29,3.02,3.59,3.86,4.54,6.26,6.78,6.89,7.15,7.35,7.40,7.66,8.45,9.16$, 9.81, 11.64, 12.65, 24.12, 24,60, 27.28, 27.74. Evans' method (MeCN-d $\left.d_{3}, 300 \mathrm{MHz}, 298 \mathrm{~K},\right)$, $\mu_{\mathrm{eff}}=5.07 \mu_{\mathrm{B}}$.

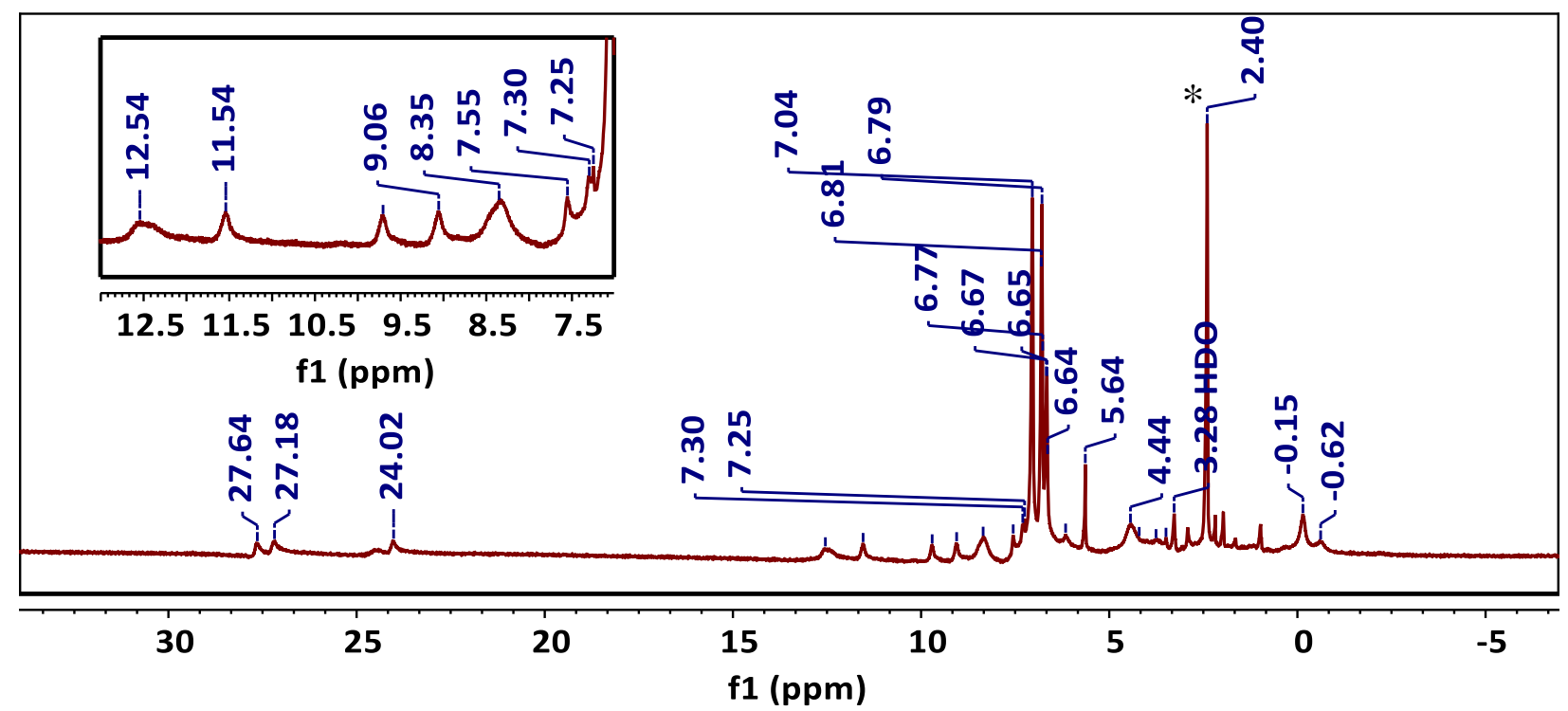

Figure S8: ${ }^{1} \mathrm{H}$ NMR spectrum of $[3]\left[\mathrm{BPh}_{4}\right]_{2}$ in DMSO- $d_{6}{ }^{*}$

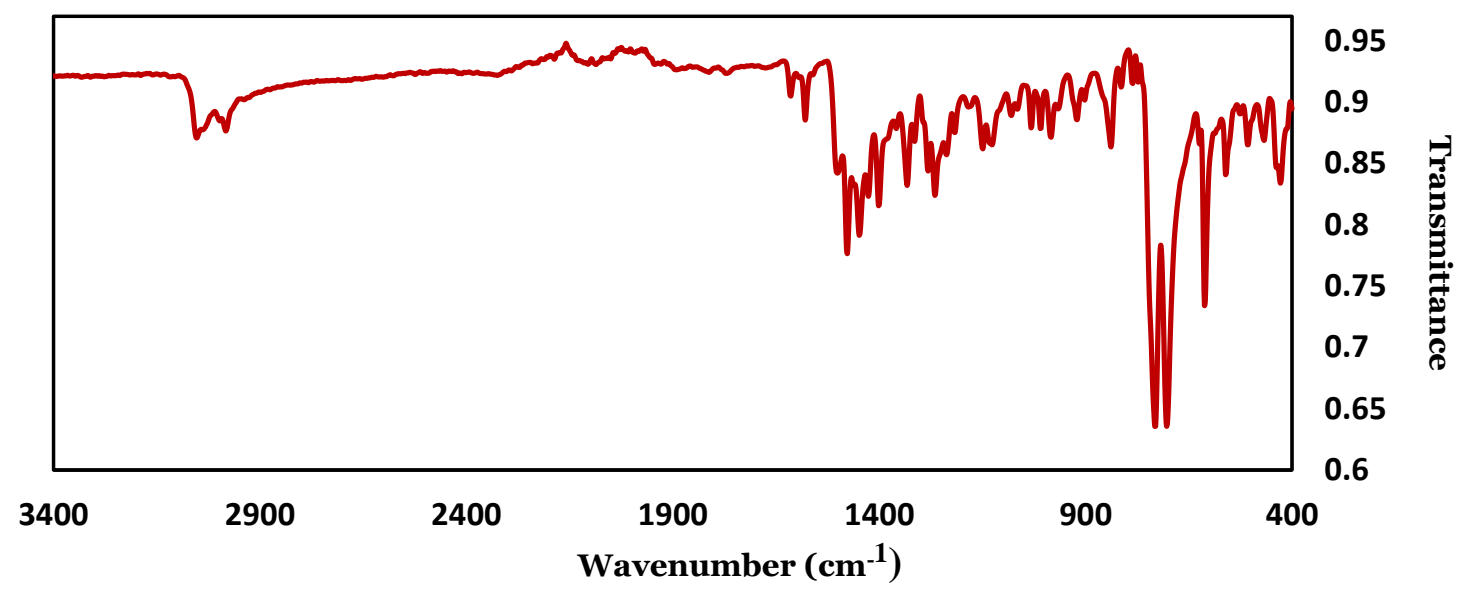

Figure S9: ATR-FTIR spectrum of $[3]\left[\mathrm{BPh}_{4}\right]_{2}$ 


\section{Preparation of 4}

The following procedures are nearly identical, but differ slightly in workup. Isolation of [4] $]^{+}$free from $[3]^{2+}$ was not accomplished in this work. Synthesis was performed in a nitrogen filled glovebox.

$\left[\mathrm{Fe}\{\boldsymbol{T} \text { bim }\}_{2}\right][\mathrm{OTf}]_{2}\left([\mathbf{3}][\mathrm{OTf}]_{2}\right): \mathrm{Fe}(\mathrm{OTf})_{2} \cdot 2 \mathrm{MeCN}(24 \mathrm{mg}, 0.055 \mathrm{mmol})$ was stirred in $6 \mathrm{~mL}$ of acetonitrile and the ligand Tbim $(25 \mathrm{mg}, 0.055 \mathrm{mmol})$ and was added to the solution. The reaction was stirred for 1 hour and was filtered. The filtrate was reduced to $1 \mathrm{~mL}$ in volume. Crystallization of the acetonitrile reaction mixture by diethyl ether diffusion over 16 hours produced colorless microcrystalline [3][OTf $]_{2}(20 \mathrm{mg}, 56 \%$ yield). Alternatively, the reaction of two equivalents of ligand $(30 \mathrm{mg}, 0.069 \mathrm{mmol})$ with one equivalent of the metal salt $\mathrm{Fe}(\mathrm{OTf})_{2}(12 \mathrm{mg}$, $0.035 \mathrm{mmol})$ in $5 \mathrm{~mL}$ of acetonitrile also produced colorless microcrystals of [3][OTf $]_{2}(25 \mathrm{mg}, 60 \%)$. ATR-FTIR $\left(\mathrm{cm}^{-1}\right): 1452,1405,1254,1153,1028,741,637 .{ }^{1} \mathrm{H} \mathrm{NMR}\left(\mathrm{MeCN}_{3}, 300 \mathrm{MHz}\right): \delta$-45.93, -8.96, -2.10, -0.45, 4.71, 5.05, 5.62, 7.74, 7.97, 8.93, 9.11, 9.63, 10.27, 11.78, 12.49, 12,83, 13.61, 18.68, 23.81, 24.01, 27.05, 27.63, 27.93, 51.74. ${ }^{19} \mathrm{~F}\left\{{ }^{1} \mathrm{H}\right\}$ NMR $\left(\mathrm{MeCN}_{3},{ }_{3}, 282.33 \mathrm{MHz}\right): \delta-79.76$. HRMS (LDI/FT-ICR) m/z: Calcd for $\{[3][\mathrm{OTf}]\}^{+}$ 1073.33076; Found 1073.32556. Anal. Calcd (found) for [3][OTf] $]_{2} \mathrm{C}_{56} \mathrm{H}_{5} 2 \mathrm{~N}_{12} \mathrm{O}_{6} \mathrm{~S}_{2} \mathrm{~F}_{6} \mathrm{Fe}$ : C, 54.99 (54.43); H, 4.29 (4.18); N, 13.74 (14.0). Evans' method ( $\mathrm{MeCN}-d_{3}, 300 \mathrm{MHz}, 298 \mathrm{~K}$, ), $\mu_{\text {eff }}=5.06 \mu_{\mathrm{B}}$.

$\left[\right.$ Fe $\{$ Tbim $\left.\}(\mathrm{MeCN})_{2}(\mathrm{OTf})\right][\mathrm{OTf}]$ ([4][OOTf]): $\mathrm{Fe}(\mathrm{OTf})_{2} \cdot 2 \mathrm{MeCN}(36 \mathrm{mg}, 0.083 \mathrm{mmol})$ and Tbim (30 mg, o.069 $\mathrm{mmol}$ ) was stirred in $4.5 \mathrm{~mL}$ of acetonitrile for 1 hour. The resulting solution was pumped off until only trace amounts of acetonitrile remained. The solid/residue was dissolved in $4.5 \mathrm{~mL}$ of dichloromethane and was stirred for 1 hour. The solution was filtered to remove unreacted $\mathrm{Fe}(\mathrm{OTf})_{2}$ and $\left[\mathrm{Fe}\{\mathbf{T b i m}\}_{2}\right][\mathrm{OTf}]_{2}$. A drop cast IR of the dichloromethane filtrate indicate the presence of [4][OTf] in solution. Diethyl ether diffusion into the reaction filtrate formed colorless crystals of [4][OTf] (26 mg, 43\% yield) accompanied with microcrystalline [3][OTf $]_{2}$. ATR-FTIR ( $\left.\mathrm{cm}^{-1}\right)$ : for crystalline [4][OTf] 2978, 2931, 2309, 2279, 1657, 1616, 1596, 1454, 1282, 1236, 1221, 1149, 1028, 748, 634. ${ }^{1} \mathrm{H}$ NMR (MeCN-d $\left.d_{3}, 400 \mathrm{MHz}\right): \delta$-8.95, -2.97 -2.10, 3.27, 3.42, 7.72, 8.69, 8.89, 9.70, 11.94, $13.58,15.84,18.65,23.94,26.67,26.98,32.00 .{ }^{19} \mathrm{~F}\left\{{ }^{1} \mathrm{H}\right\}$ NMR (MeCN- $\left.d_{3}, 282.33 \mathrm{MHz}\right): \delta-72.94 . \mathrm{CHN}$ and HRMS always contained significant amounts of $[3]^{2+}$. HRMS (LDI/FT-ICR) $\mathrm{m} / \mathrm{z}$ : Calcd for $\{\mathrm{Fe}+\mathbf{T b i m}+\mathrm{OTf}\}^{+}$ 639.10886; Found 639.10884.

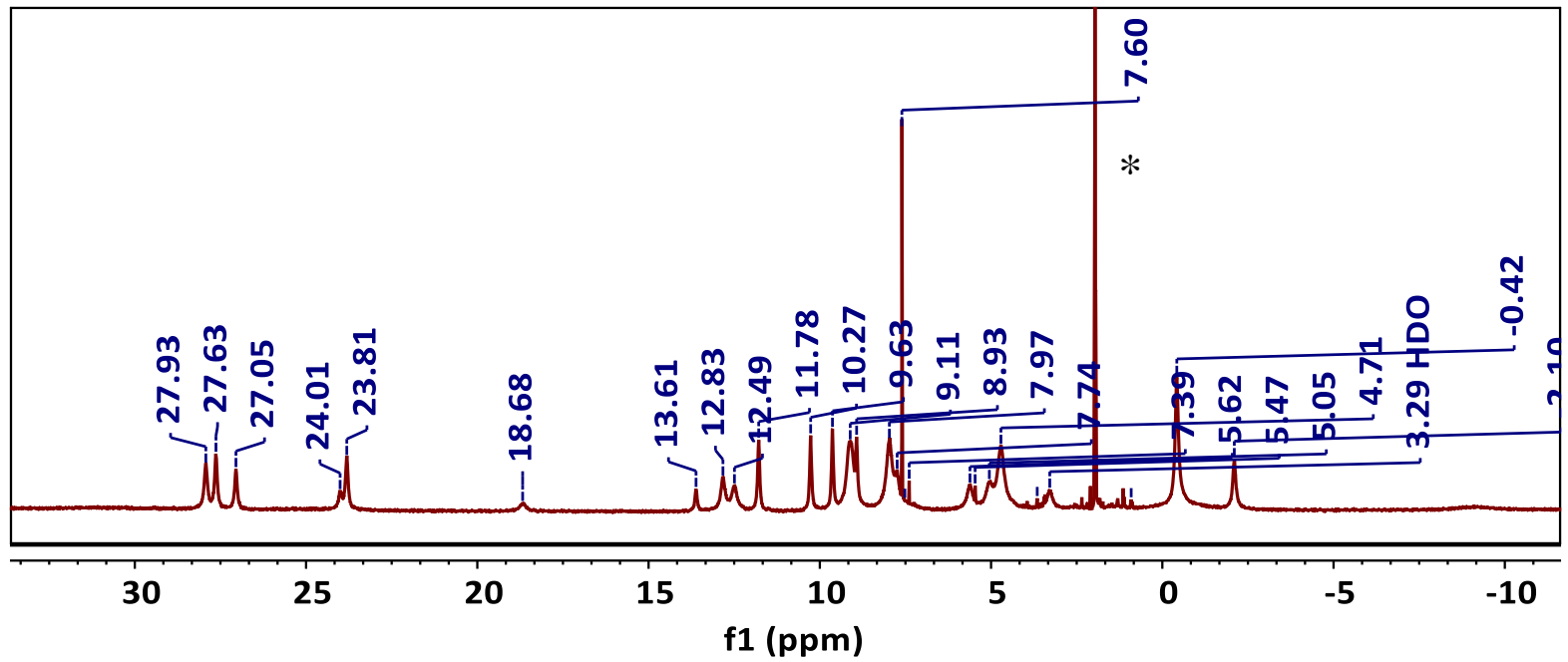

Figure S10: ${ }^{1} \mathrm{H}$ NMR spectrum of $[3][\mathrm{OTf}]_{2}$ in $\mathrm{MeCN}-d_{3}{ }^{*}$

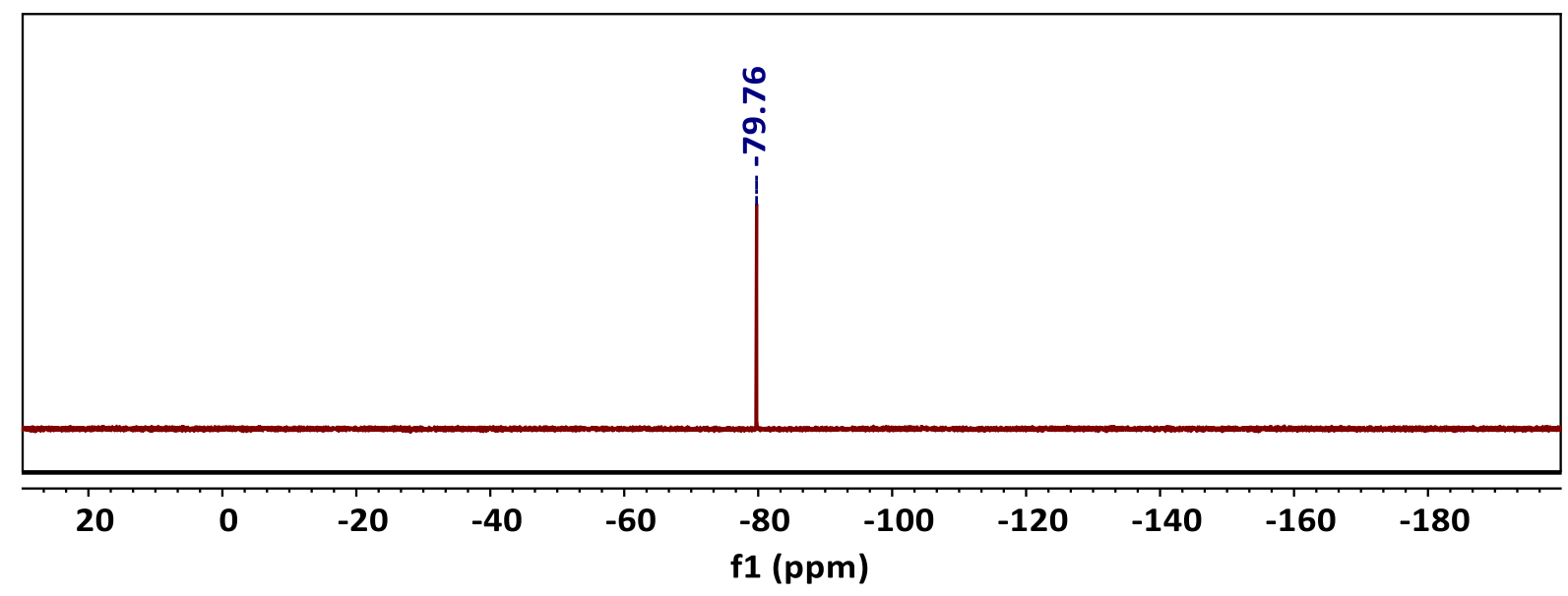

Figure S11: ${ }^{19} \mathrm{~F}\{1 \mathrm{H}\}$ NMR spectrum of $[3][\mathrm{OTf}]_{2}$ in $\mathrm{MeCN}-d_{3}$ 


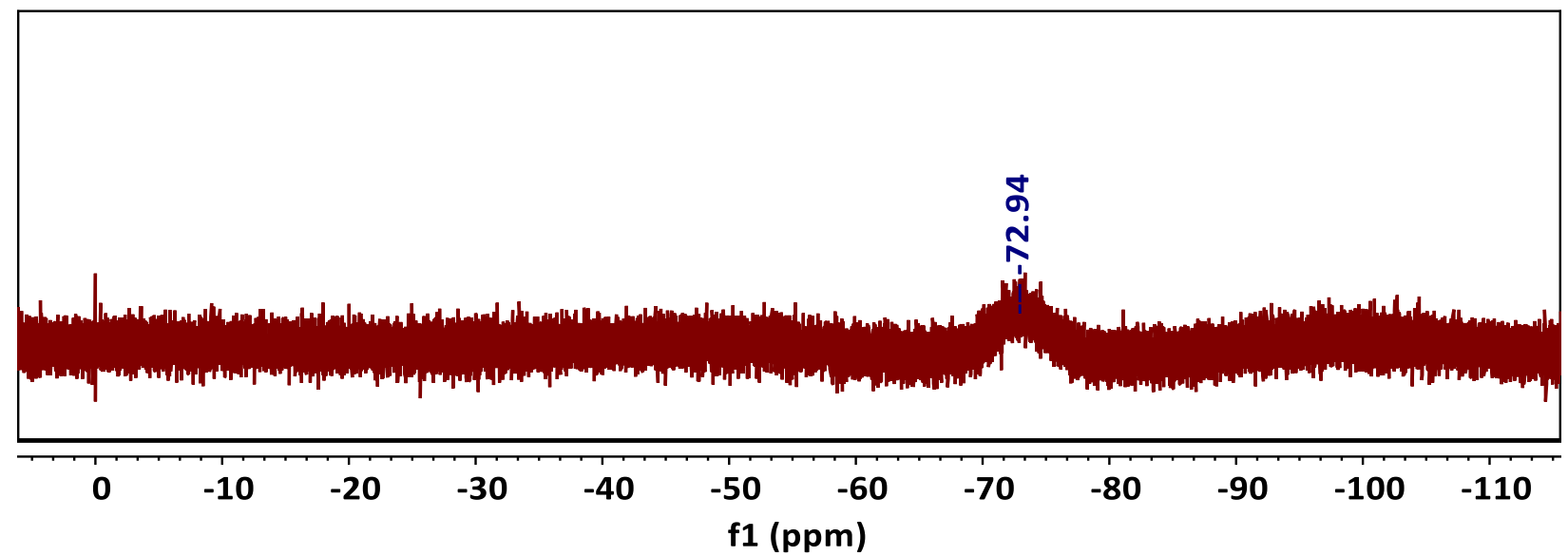

Figure S12: ${ }^{19} \mathrm{~F}\left\{{ }^{1} \mathrm{H}\right\}$ NMR spectrum of $1: 1$ mixture of Tbim and $\mathrm{Fe}(\mathrm{OTf})_{2} \cdot 2 \mathrm{MeCN}$ in $\mathrm{MeCN}-d_{3}$

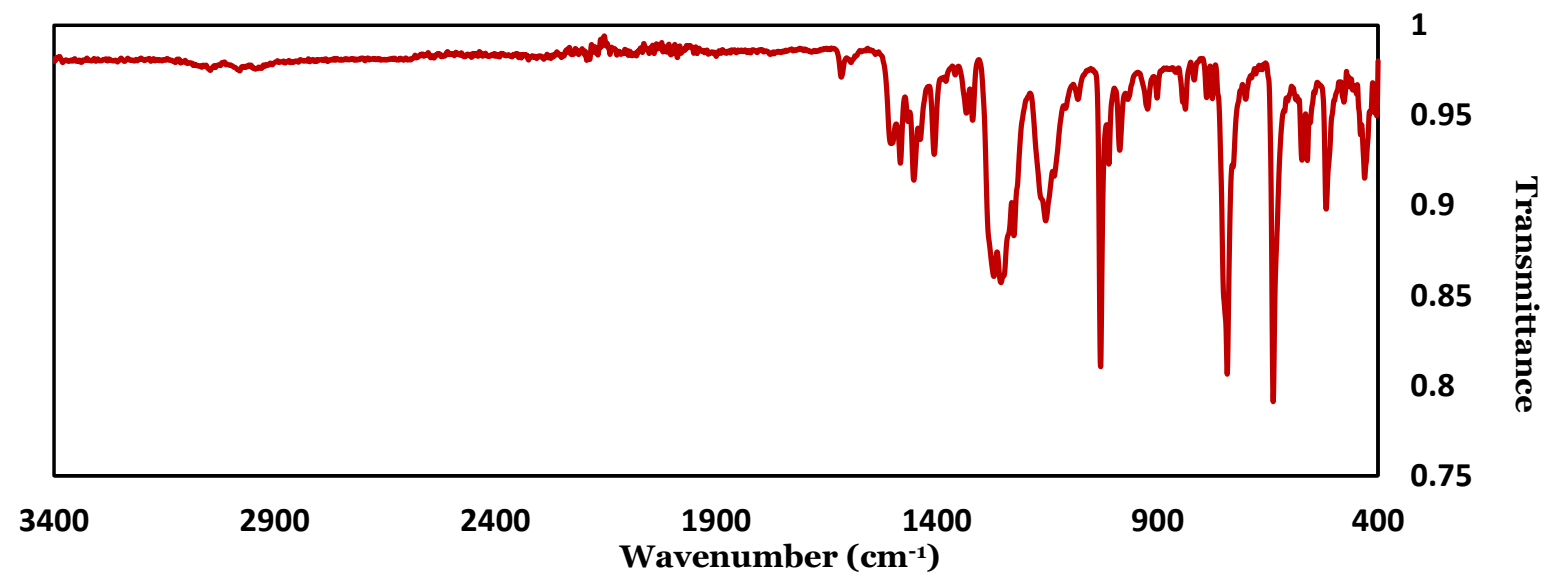

Figure S13: ATR-FTIR spectrum of $[3][\mathrm{OTf}]_{2}$

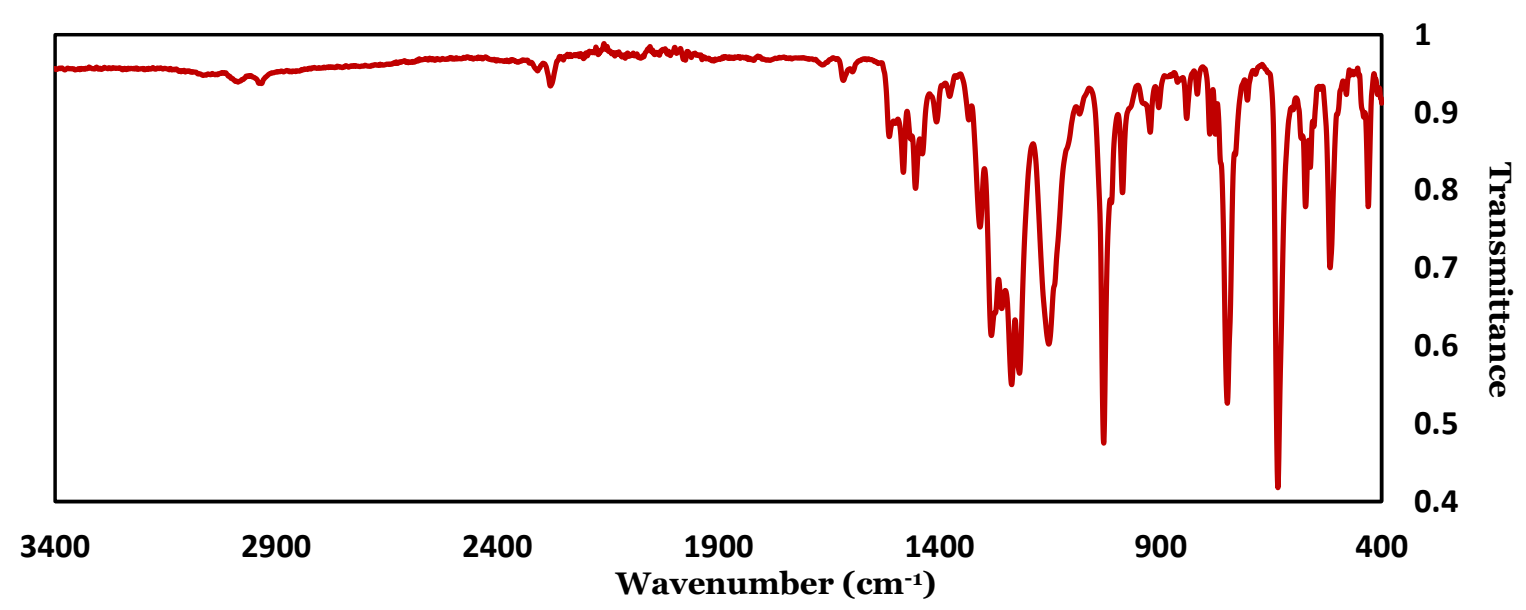

Figure S14: ATR-FTIR spectrum of [4][OTf] with MeCN stretches. 

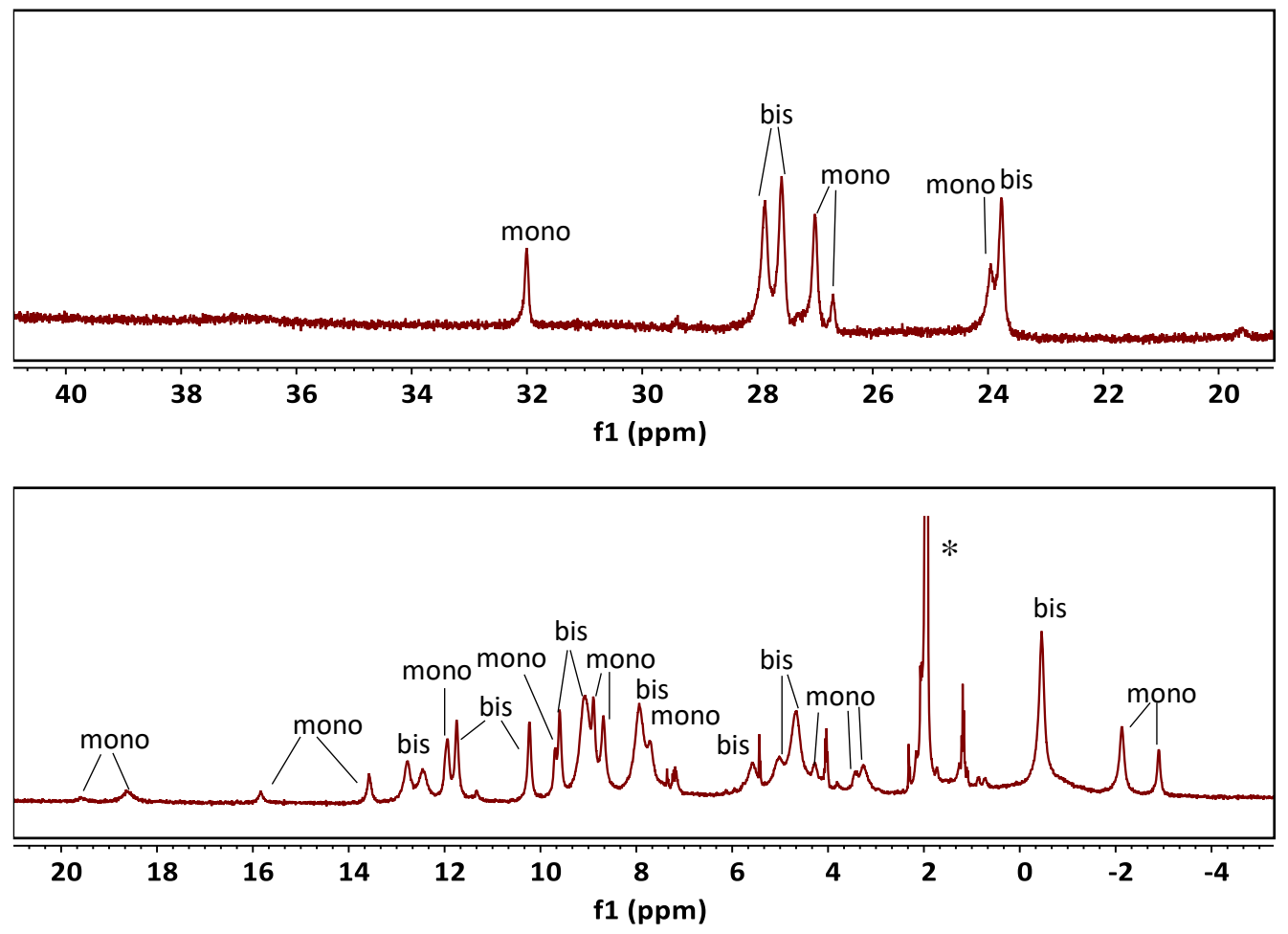

Figure S15: ${ }^{1} \mathrm{H}$ NMR spectrum indicating the presence of $[3][\mathrm{OTf}]_{2}$ (bis) and [4][OTf] (mono) in MeCN- $d_{3}{ }^{*}$

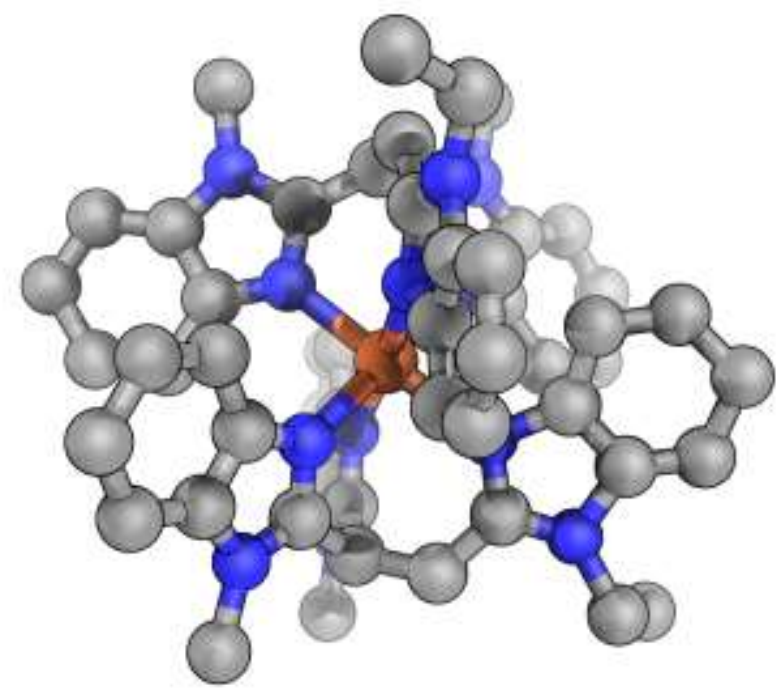

Figures S16: XRD determined connectivity structure of $[3]^{2+}$ (crystallized as the tetraphenylborate salt). Hatoms, counterions, and solvent molecules are not shown. Color scheme: orange $=\mathrm{Fe}$; blue $=\mathrm{N}$; grey $=\mathrm{C}$. 
Procedure for determining optimal ligand-metal ratio for in-situ $[4]^{+}:$Stock solutions of $25 \mathrm{mM}$ Tbim and $\mathrm{Fe}(\mathrm{OTf})_{2} \bullet 2 \mathrm{MeCN}$ (or Fe(OTf) $)_{2} \bullet 6 \mathrm{H}_{2} \mathrm{O}$ ) were prepared in $\mathrm{MeCN}-d_{3}$. The stock solutions of the Tbim and $\mathrm{Fe}^{2+}$ were mixed in different ratios to achieve the desired mole fractions and the total volume was adjusted to $3 \mathrm{~mL}$ using $\mathrm{MeCN}-d_{3}$. The peak at $32 \mathrm{ppm}$, which was identified as a unique peak for $[4]^{+}$, was chosen to construct the plot. The width at half maximum of the $32 \mathrm{ppm}$ peak was measured against the width at half maximum of $\mathrm{CH}_{3}$ peak of toluene (2.29 ppm, internal standard) or the peak height of acetonitrile (1.94 ppm) in the solution to arrive at a relative intensity value at each mole fraction. The plot was constructed by plotting the relative peak height vs. the mole fraction of Tbim/Fe(OTf $)_{2}$. This measurement was replicated four times, each time with the optimal ratio near 3:2 for metal:ligand.

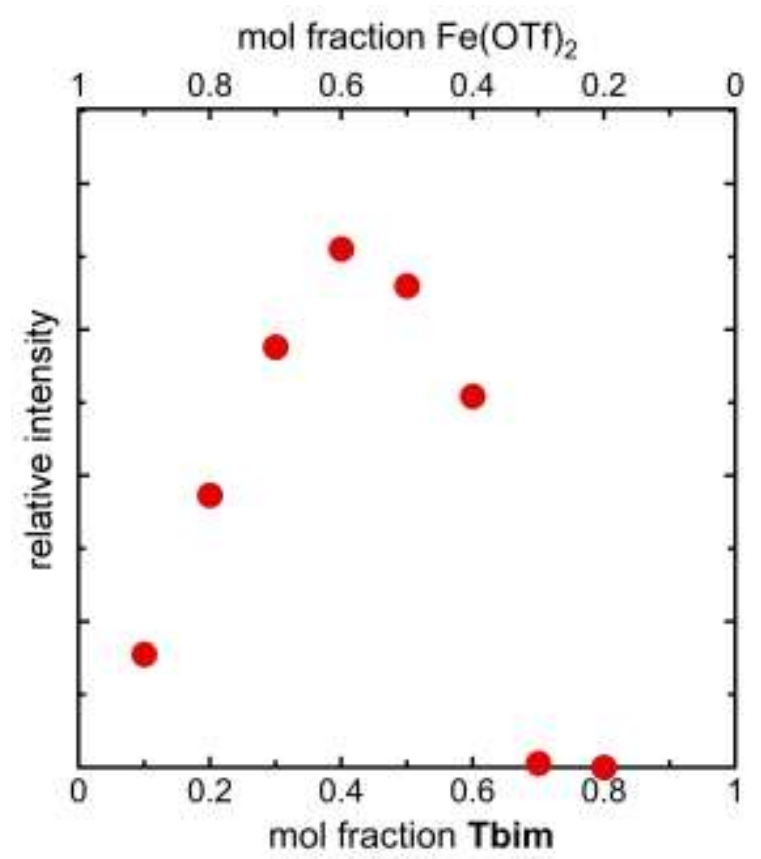

Figure S17: Plot for determining the optimal mole ratio for in situ preparation of [4] using $\mathrm{Fe}(\mathrm{OTf})_{2} \cdot 6 \mathrm{H}_{2} \mathrm{O}$. 
The $\mathrm{p} K_{\mathrm{a}}$ (water) values of 1,2-dimethylbenzimidazole were measured with modifications to the procedures reported by Dardonville et. al. and Benkovic et. al.18,19 Stock solutions of the salts used for buffers were prepared by dissolving the respective salts to get $0.05 \mathrm{M} \mathrm{NaH}_{2} \mathrm{PO}_{4}$, $0.1 \mathrm{M} \mathrm{NaOAc}$, $0.025 \mathrm{M} \mathrm{Na}_{2} \mathrm{~B}_{4} \mathrm{O}_{7}$ and $0.1 \mathrm{M}$ trisodium citrate. $0.1 \mathrm{M} \mathrm{HCl}$ was standardized using $0.1 \mathrm{M} \mathrm{K}_{2} \mathrm{CO}_{3}$ and $0.1 \mathrm{M} \mathrm{NaOH}$ was standardized with the $\mathrm{HCl}$ solution. The buffer solutions were prepared by measuring $50.0 \mathrm{~mL}$ of the appropriate salt solution in a $100.0 \mathrm{~mL}$ volumetric flask and adjusting the $\mathrm{pH}$ using $\mathrm{HCl}$ or $\mathrm{NaOH}$. The ionic strengths of the solutions were calculated using equation 1 and were adjusted to $0.1 \mathrm{M}$ by addition of $\mathrm{KCl}$. The final volume of the buffer solutions was adjusted to $100.0 \mathrm{~mL}$ with distilled water.

$$
I=\frac{1}{2} \sum_{i=1}^{n} c_{i} Z_{i}
$$

equation $S 1$

The stock solution of the 1,2-dimethylbenzimidazole was prepared by dissolving of $45 \mathrm{mg}$ of 1,2dimethylbenzimidazole in $3.0 \mathrm{~mL}$ of DMSO. The solutions for the UV-vis experiment was prepared by diluting $20 \mu \mathrm{L}$ of the stock solution of 1,2-dimethylbenzimidazole to $10.0 \mathrm{~mL}$ with the respective buffer solutions. The absorbance spectra of the solution were measured between $200-400 \mathrm{~nm}$ and the spectra were normalized to 400 $\mathrm{nm}$. The spectral difference at the lowest $\mathrm{pH}$ and each spectrum in different $\mathrm{pH}$ was obtained. The wavelengths that produce the highest positive absorbance and the highest negative absorbance were selected. The total absorbance at a given $\mathrm{pH}$ was calculated by addition of absolute values of the absorbance at the chosen wavelengths and was plotted against the $\mathrm{pH}$. The $\mathrm{p} K_{\mathrm{a}}$ was determined using Origin 2019 by nonlinear regression of equation 2.

$$
\text { Total absorbance }=\frac{\left[\varepsilon_{H A}-\varepsilon_{A}\right]\left[10^{(p H-p K a)}\right]}{1+10^{(p H-p K a)}} \cdot\left[S_{t}\right]
$$

equation $\mathrm{S2}$

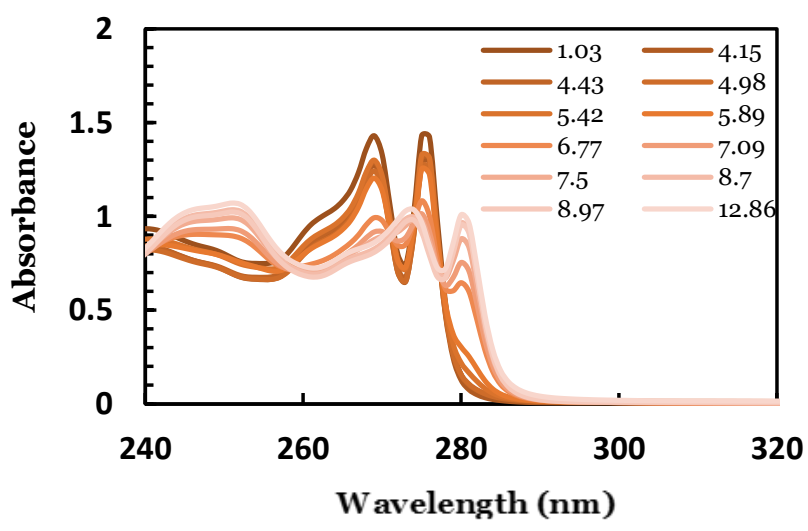

(a)

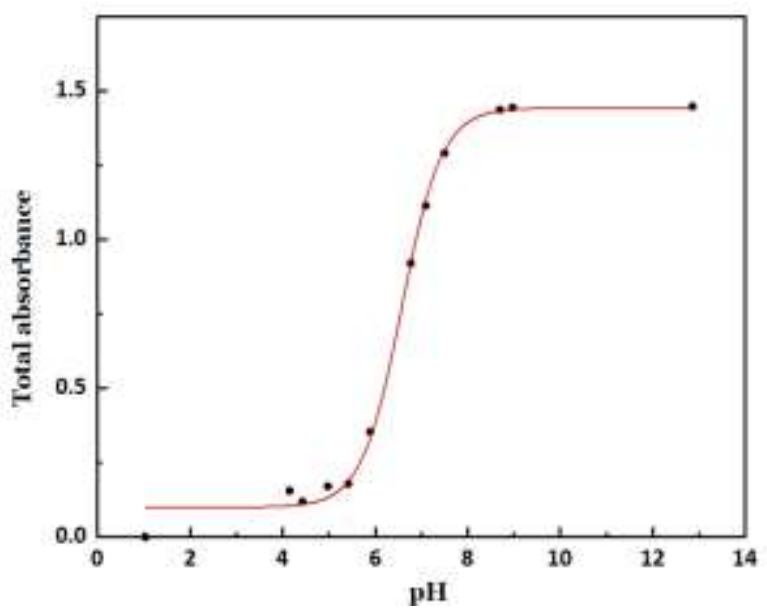

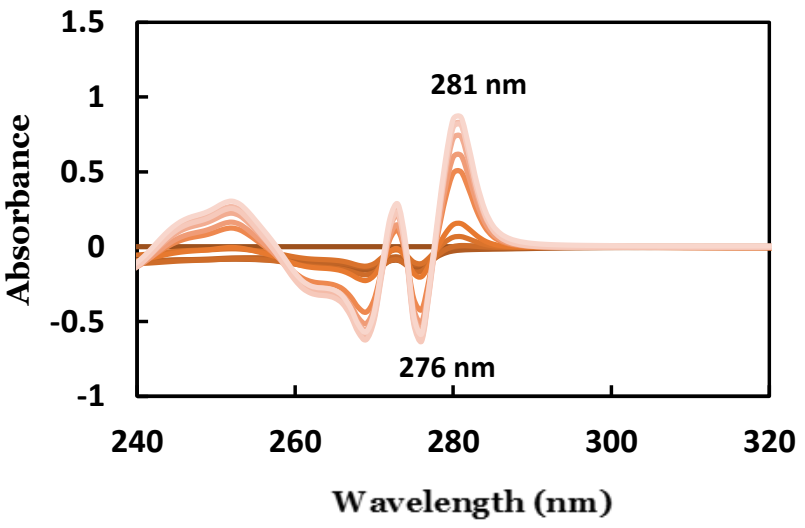

(b)

(c)

Figure 18: (a) UV-vis spectra of 1,2-dimethylbenzimidazole in different $\mathrm{pH}$ buffer solutions (normalized at 400 $\mathrm{nm}$ ), (b) Plot of the spectral difference between different solutions of 1,2-dimethylbenzimidazole in buffer solutions and (c) Total absorbance difference vs $\mathrm{pH}$ graph for determination of $\mathrm{p} K_{\mathrm{a}}$. 
Table S1. $\mathrm{p} K_{\mathrm{a}}\left(\mathrm{H}_{2} \mathrm{O}\right)$ values used for Figure 1 and Figure $\mathrm{S19}^{20}$

\begin{tabular}{c|c|c}
\hline conjugate acid of... & $\mathbf{p} \boldsymbol{K}_{\mathbf{a}}$ & ref \\
\hline pyrrole & -0.38 & 21 \\
\hline pyrazole & 2.49 & 21 \\
\hline pyridine & 5.23 & 21,22 \\
\hline benzimidazole & 5.43 & 23 \\
\hline$N$-methylbenzimidazole & 5.55 & 24 \\
\hline histidine & 6.04 & 21 \\
\hline 2-methylbenzimidazole & 6.19 & 21,24 \\
\hline 1,2-dimethylbenzimidazole & 6.57 & 21,25 \\
\hline imidazole & 6.99 & 25 \\
\hline$N$-methylimidazole & 7.21 & 25 \\
\hline 4-methylimidazole & 7.69 & 21 \\
\hline trimethylamine & 9.80 & 26 \\
\hline H ${ }_{3}$ TACN & 10.44 & 21 \\
\hline triethylamine & 10.75 & 21 \\
\hline diethylamine & 10.84 & 21 \\
\hline guanidine & 13.6 & work (see above) \\
\hline
\end{tabular}

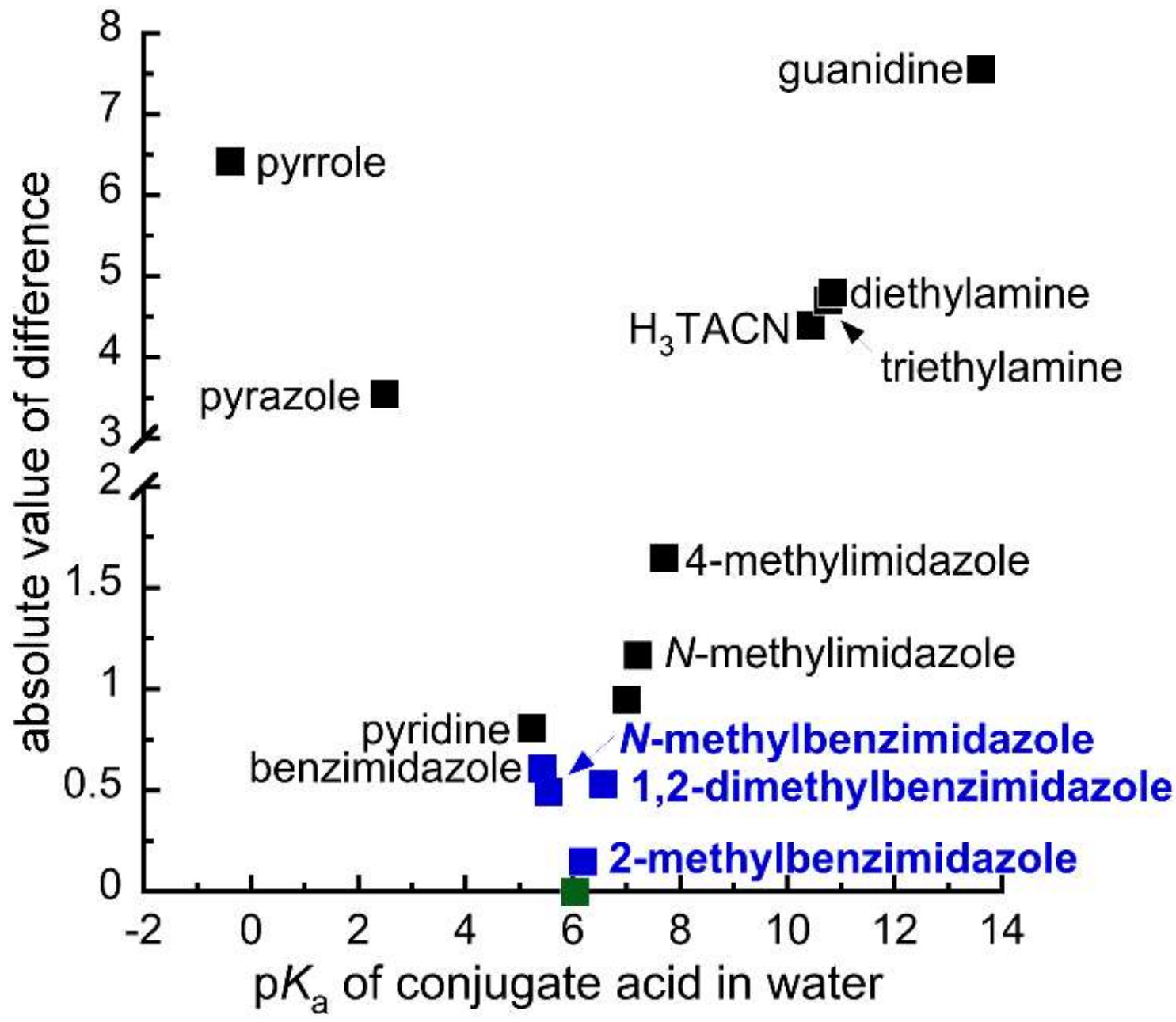

Figure S19: Comparison of ligand conjugate $\operatorname{acid} \mathrm{p} K_{\mathrm{a}}$ to histidine. 


\section{Catalysis}

Li[Phmal] oxidation: Following the literature method, ${ }^{27}$ dry oxygen was bubbled through a reaction mixture with $5 \mathrm{~mol} \%$ catalyst in dry acetonitrile over 1 hour and diethyl 2-hydroxy-2-phenylmalonate (HOPhmal) was obtained as the major product; the biomimetic product the ethyl benzoylformate was only a minor product. An increase in ethyl benzoylformate yield was observed for dropwise addition of the substrate with otherwise identical procedures.

The flasks used for catalysis were assembled inside a nitrogen filled glovebox and reactions were performed on a Schlenk line. Stock solutions of Tbim $(17.8 \mathrm{mg}, 0.0410 \mathrm{mmol}),\left[\left\{\mathrm{Tp}{ }^{*}\right\} \mathrm{Fe}(\mathrm{Phmal})\right](24.1 \mathrm{mg}$, $0.0410 \mathrm{mmol}), \mathrm{Fe}(\mathrm{OTf})_{2} \cdot 2 \mathrm{MeCN}(67.6 \mathrm{mg}, 0.155 \mathrm{mmol})$ were prepared by dissolving the respective compound in dry acetonitrile and volume was adjusted to $5.0 \mathrm{~mL}$. To produce the catalysts [4][OTf] (mono complex) and [3][OTf $]_{2}$ (bis complex) in situ, stock solutions of the ligand and the metal were mixed in mole ratios deduced from the plot discussed above (Figure S17) prior to the catalysis. The substrate Li[Phmal] (20.0 mg, 0.0826 $\mathrm{mmol}$ ) was dissolved in $5 \mathrm{~mL}$ of dry acetonitrile and loaded to an addition funnel. The respective catalysts were prepared in $3 \mathrm{~mL}$ of dry acetonitrile in a Schlenk flask and stirred for 5 minutes. The setup was taken out from the glovebox and assembled on a Schlenk line. The substrate was gradually added over a period of 15 minutes via a drop funnel and a cannula was inserted for addition of dry oxygen (oxygen was dried by flowing gas through a Drierite column followed by chilled glass tubing, $-78^{\circ} \mathrm{C}$ ). Note that, immediately following the start of substrate addition oxygen bubbling was initiated, where the cannula was submerged and oxygen was bubbled through the solution. After complete addition of substrate, the funnel was washed with $2 \mathrm{~mL}$ of dry acetonitrile and was subsequently added dropwise to the same reaction mixture. Oxygen was bubbled for a total of 1 hour after which $0.5 \mathrm{~mL}$ of $3 \mathrm{M} \mathrm{HCl}$ was added. The total volume of the solution was adjusted to $10 \mathrm{~mL}$ in a volumetric flask with acetonitrile. $200 \mu \mathrm{L}$ of this solution was treated with a known amount internal standard (anthracene dissolved in DCM) and then diluted to $5 \mathrm{~mL}$ with DCM and directly analyzed using GC-MS. Yields were determined using calibration curves prepared from independently synthesized products and reagents with anthracene as the internal standard.

Table S2: Results from catalytic aerobic oxidation of lithium diethyl 2-phenylmalonate (Li[Phmal]) (dropwise addition of substrate).

\begin{tabular}{l|cc|cc|cc}
\hline \multirow{2}{*}{ Catalyst } & \multicolumn{2}{|c|}{ HPhmal (\%) } & \multicolumn{2}{c|}{ Et-benzoylformate (\%) } & \multicolumn{2}{c}{ HOPhmal (\%) } \\
\cline { 2 - 7 } Fe/Tbim (3:2) & run 1 & run 2 & run 1 & run 2 & run 1 & run 2 \\
Fe/Tbim (1:4) & O & o & 18 & 25 & 50 & 31 \\
Fe/no ligand & O & 0 & 15 & 19 & 61 & 40 \\
Fe/Ph $\mathbf{N H}$ & 0 & 0 & 14 & 18 & 42 & 40 \\
no iron or ligand & 54 & 68 & 0 & 0 & 13 & 20 \\
\hline
\end{tabular}




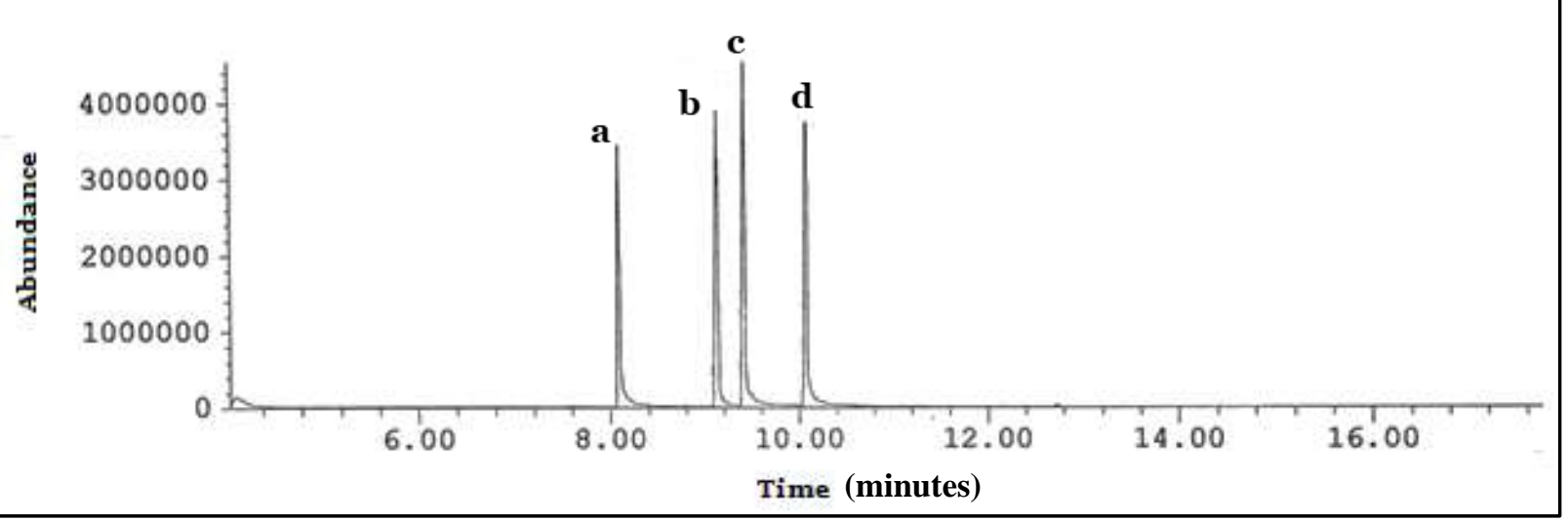

Figure S20: GC trace for HPhmal and its oxidation products prepared independently. a: ethyl benzoylformate, b: HPhmal, c: HOPhmal and d: anthracene internal standard.

Ethyl benzoylformate: ${ }^{1} \mathrm{H}$ NMR (Chloroform- $d$, $\left.300 \mathrm{MHz}\right): \delta 1.39(\mathrm{t}, 2 \mathrm{H}), 4.41(\mathrm{q}, 2 \mathrm{H}), 7.48(\mathrm{tt}, 2 \mathrm{H}$, aromatic), 7.63 (tt, $1 \mathrm{H}$, aromatic), 7.97 (d, $2 \mathrm{H}$, aromatic). ${ }^{13} \mathrm{C}$ NMR (Chloroform- $d, 75 \mathrm{MHz}$ ): $\delta$ 14.26, $62.47,129.03,130.17,132.63,135.03,163.96,186.56$.

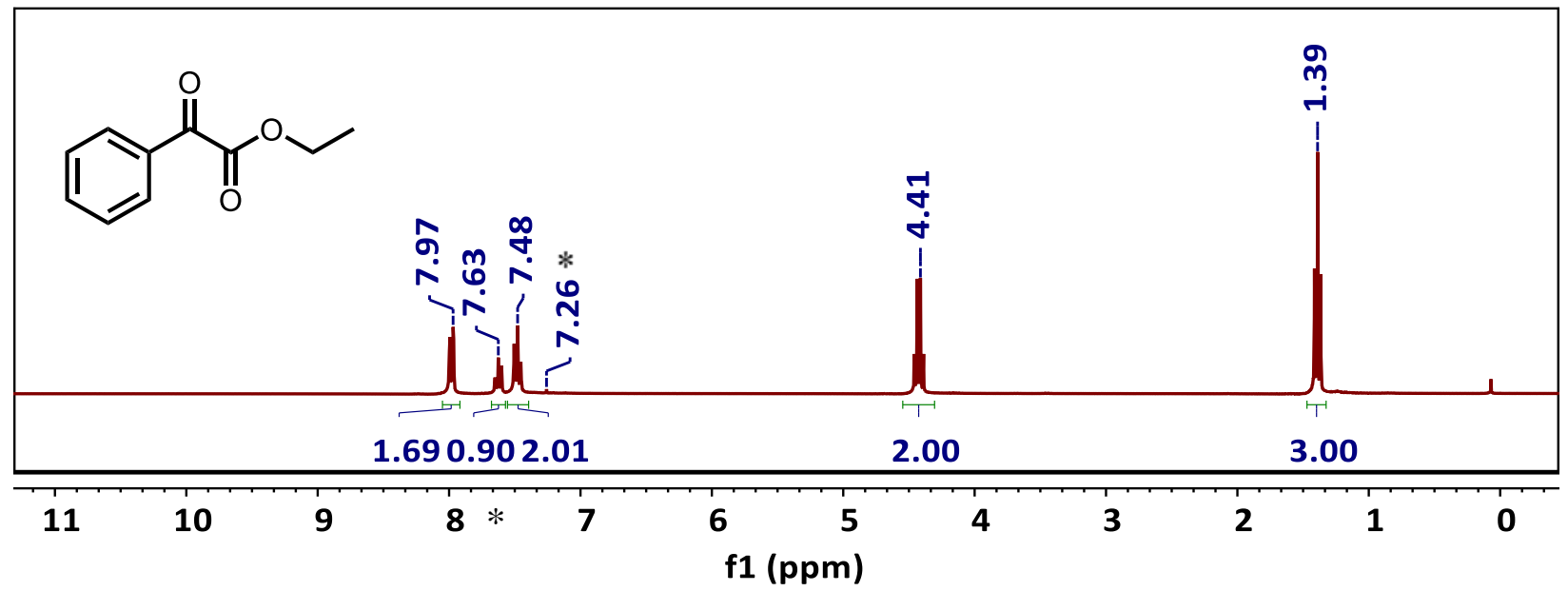

Figure S21: ${ }^{1} \mathrm{H}$ NMR spectrum of ethyl benzoylformate in chloroform- $d^{*}$

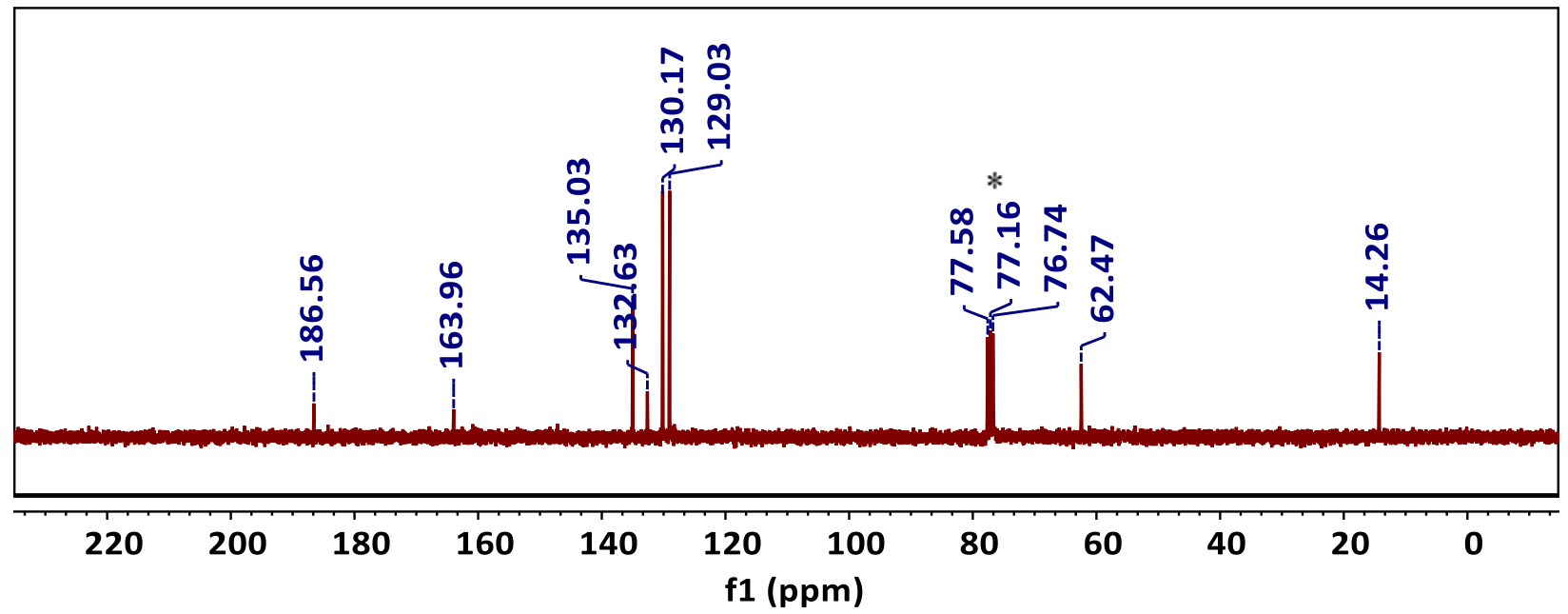

Figure S22: ${ }^{13} \mathrm{C}$ NMR spectrum of ethyl benzoylformate in chloroform- $d^{*}$ 
Diethyl 2-hydroxy-2-phenylmalonate (HOPhmal): Diethyl 2-hydroxy-2-phenylmalonate (HOPhmal) was prepared according to the following procedure: LiPhmal (32 mg, $0.132 \mathrm{mmol}$ ) was stirred with $5 \mathrm{~mL}$ of dry acetonitrile in the presence of air for 16 hours. The solution was treated with $0.5 \mathrm{~mL}$ of $3 \mathrm{M} \mathrm{HCl}$ and the solvent was removed under vacuum. The aqueous layer was extracted with $3 \times 2 \mathrm{~mL}$ of dichloromethane and the solvent evaporated to obtain the product as a colorless clear liquid (23 mg, 70\% yield). ${ }^{1} \mathrm{H}$ NMR data matches with the literature reported values. ${ }^{28}{ }^{1} \mathrm{H}$ NMR (Chloroform- $d$, $\left.300 \mathrm{MHz}\right): \delta 1.28\left(\mathrm{t}, 6 \mathrm{H}, \mathrm{CH}_{3}\right), 4.30\left(\mathrm{q}, 4 \mathrm{H}, \mathrm{CH}_{2}\right), 4.40(\mathrm{br}$, $1 \mathrm{H}, \mathrm{OH}$ ), 7.36 (m, $3 \mathrm{H}$, aromatic), 7.65 (d, $2 \mathrm{H}$, aromatic). ${ }^{13 \mathrm{C} N M R}$ (Chloroform- $d, 75 \mathrm{MHz}$ ): $\delta$ 169.9, 136.0, 128.6, 128.0, 126.7, 80.0, 63.0, 14.0.

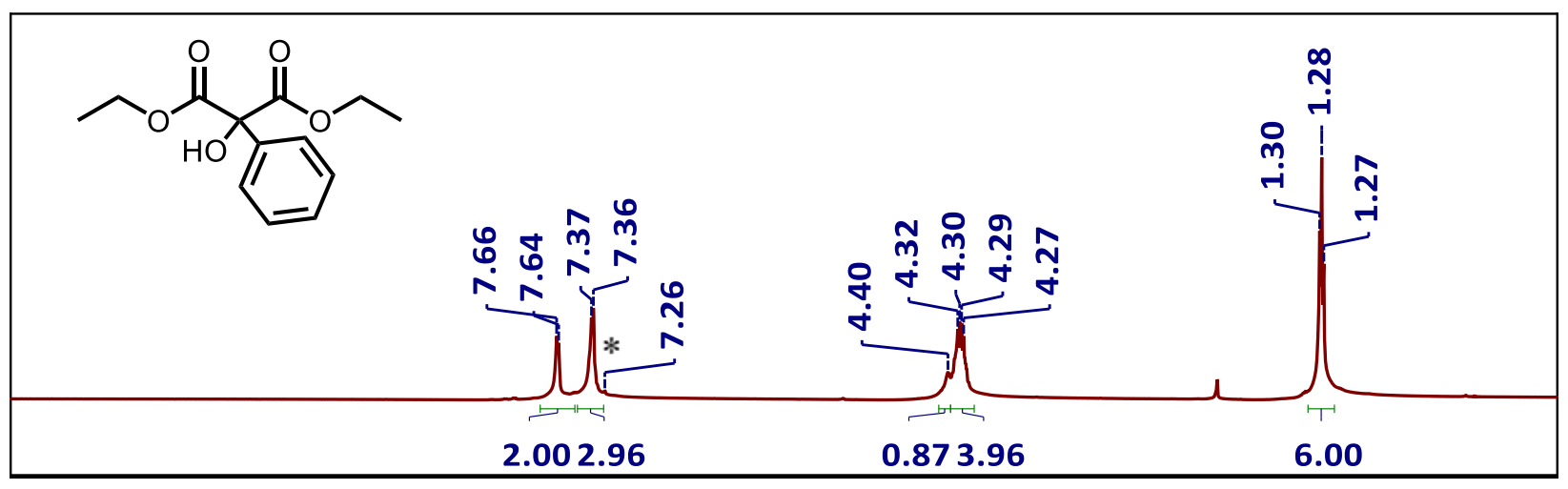
12
$11 \quad 10$
9
8
7
6
5
43
32
10
f1 (ppm)

Figure S23: ${ }^{1} \mathrm{H}$ NMR spectrum of HOPhmal in chloroform- $d^{*}$

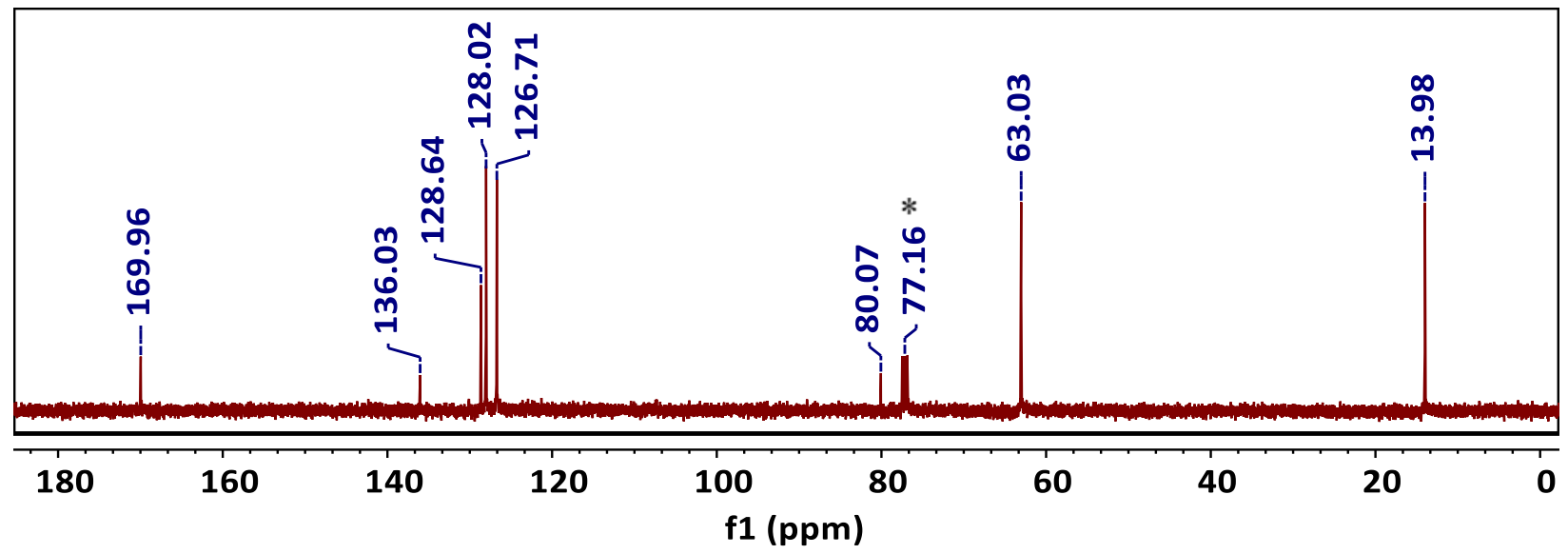

Figure S24: ${ }^{13} \mathrm{C}$ NMR spectrum of HOPhmal in chloroform- $d^{*}$ 
Determination of Schlenk equilibrium from DFT: The Gibb's free energy changes at standard conditions in gas phase $\left(\Delta G_{\mathrm{gas}}\right)$ and in $\mathrm{MeCN}\left(\Delta G_{\mathrm{MeCN}}\right)$ were calculated for the following reactions;

$$
\begin{aligned}
& {\left[\mathrm{Fe}(\text { Tbim })_{2}\right][\mathrm{OTf}]_{2}+2 \mathrm{MeCN} \rightleftharpoons\left[\mathrm{Fe}(\text { Tbim })(\mathrm{MeCN})_{2}(\mathrm{OTf})\right][\mathrm{OTf}]+\text { Tbim } \quad \text { Rxn. } 1} \\
& {\left[\mathrm{Fe}(\text { Tbim })_{2}\right][\mathrm{OTf}]_{2}+\text { trans }-\left[\mathrm{Fe}(\mathrm{MeCN})_{4}(\mathrm{OTf})_{2}\right] \rightleftharpoons 2\left[\mathrm{Fe}(\mathrm{Tbim})(\mathrm{MeCN})_{2}(\mathrm{OTf})\right][\mathrm{OTf}] \quad \text { Rxn. } 2} \\
& \text { trans }-\left[\mathrm{Fe}(\mathrm{MeCN})_{4}(\mathrm{OTf})_{2}\right]+\text { Tbim } \rightleftharpoons\left[\mathrm{Fe}(\text { Tbim })(\mathrm{MeCN})_{2}(\mathrm{OTf})\right][\mathrm{OTf}]+2 \mathrm{MeCN} \quad \text { Rxn. } 3 \\
& \text { trans }-\left[\mathrm{Fe}(\mathrm{MeCN})_{4}(\mathrm{OTf})_{2}\right]+2 \text { Tbim } \rightleftharpoons\left[\mathrm{Fe}(\text { Tbim })_{2}\right][\mathrm{OTf}]_{2}+4 \mathrm{MeCN} \quad \text { Rxn. } 4
\end{aligned}
$$

Table S3: DFT computed Gibbs's free energies for Schlenk equilibrium

\begin{tabular}{c|c|c}
\hline Reaction & $\Delta G_{\text {gas }}(\mathrm{kcal} / \mathbf{m o l})$ & $\Delta G_{\text {MeCN }}(\mathrm{kcal} / \mathbf{m o l})$ \\
\hline Rxn. 1 & -96.75 & +32.31 \\
Rxn. 2 & -41.91 & +3.163 \\
Rxn. 3 & +54.84 & -29.14 \\
Rxn. 4 & +151.6 & -61.45 \\
\hline
\end{tabular}

\section{References}

1. Hagen, K. S. Iron(II) Triflate Salts as Convenient Substitutes for Perchlorate Salts:Crystal Structures of $\left[\mathrm{Fe}\left(\mathrm{H}_{2} \mathrm{O}\right)_{6}\right]\left(\mathrm{CF}_{3} \mathrm{SO}_{3}\right)_{2}$ and $\mathrm{Fe}(\mathrm{MeCN})_{4}\left(\mathrm{CF}_{3} \mathrm{SO}_{3}\right)_{2}$. Inorg. Chem. 2ooo, 39, 5867-5869.

2. lgafi, S.; Field, L. D.; Messerle, B. A.; Turner, P.; Hambley, T. W. Rhodium Complexes Containing Bidentate Imidazolyl Ligands: Synthesis and Structure. J. Organomet. Chem. 1999, 588, 69-77.

3. Sahay, I. I.; Ghalsasi, P. S. Synthesis of New 1,2,3-Triazole Linked Benzimidazole Molecules as AntiProliferative Agents. Synth. Commun. 2017, 47, 825-834.

4. Siewert, I.; Limberg, C. A Trispyrazolylborato iron malonato complex as a functional model for the acetylacetone dioxygenase. Angew. Chem. Int. Ed. 2oo8, 47, 7953-7956.

5. Yamada, T.; Kuwata, M.; Takakura, R.; Monguchi, Y.; Sajiki, H.; Sawama, Y. Organocatalytic Nitroaldol Reaction Associated with Deuterium-Labeling. Adv. Synth. Catal. 2018, 36o, 637-641.

6. Vibert, F.; Marque, S. R. A.; Bloch, E.; Queyroy, S.; Bertrand, M. P.; Gastaldi, S.; Besson, E. Design of WallFunctionalized Hybrid Silicas Containing Diazene Radical Precursors. EPR Investigation of Their Photolysis and Thermolysis. J. Phys. Chem. C. 2015, 119, 5434-5439.

7. Reichardt, C.; Erfurt, H. P.; Harms, K.; Schäfer, G. Syntheses, Absolute Configurations, and UV/Vis Spectroscopic Properties of New Chiral Tri- and Pentamethinium Streptocyanine Dyes with 4Aminophenyl 4-Methylphenyl Sulfoxide Endgroups. European J. Org. Chem. 2002, 3, 439-452.

8. Zhao, X.; Liu, T. X.; Zhang, G. Synthesis of Thiosulfonates via CuI-Catalyzed Reductive Coupling of Arenesulfonyl Chlorides Using $\mathrm{Na}_{2} \mathrm{SO}_{3}$ or $\mathrm{NaHSO}_{3}$ as Reductants. Asian J. Org. Chem. 2o17, 6, 677-681.

9. $\quad$ Kirihara, M.; Asai, Y.; Ogawa, S.; Noguchi, T.; Hatano, A.; Hirai, Y. A Mild and Environmentally Benign Oxidation of Thiols to Disulfides. Synthesis. 2007, 21, 3286-3289.

10. CrysAlisPro; Rigaku OD, The Woodlands, TX, 2015.

11. Sheldrick, G. M., SHELXT - Integrated Space-Group and Crystal-Structure Determination. Acta Cryst. 2015, $A 71,3-8$.

12. Sheldrick, G.M. A Short History of SHELX. Acta Cryst. 2008, A64, 112-122.

13. Müller, P. Practical Suggestions for Better Crystal Structures. Crystallogr. Rev. 2009, 15, 57-83.

14. (a) Neese, F. Wiley Interdiscip. Rev. Comput. Mol. Sci. 2012, 2, 73. (b) Neese, F. Wiley Interdiscip. Rev. Comput. Mol. Sci. 2018, 8, 4 .

15. (a) Grimme, S.; Ehrlich, S.; Goerigk, L. J. Comput. Chem. 2011, 32, 1456. (b) Grimme, S.; Antony, J.; Ehrlich, S.; Krieg, H. J. Chem. Phys. 2010, 132, 154104.

16. (a) Johnson E. R.; Becke, A. D. J. Chem. Phys. 2005, 123, 024101. (b) Becke, A. D.; Johnson, E. R. J. Chem. Phys. 2005, 123, 154101. (c) Johnson, E. R.; Becke, A. D. J. Chem. Phys. 2006, 124, 174104.

17. Weigend, F.; Ahlrichs, R. Phys. Chem. Chem. Phys. 2005, 7, 3297.

18. Martínez, C. H. R.; Dardonville, C. Spectroscopy Using 96-Well Microtiter Plates. ACS Med. Chem. Lett. 2013, 4, 142-145.

19. Tomsho, J. W.; Pal, A.; Hall, D. G.; Benkovic, S. J. Ring Structure and Aromatic Substituent Effects on the $\mathrm{p} K_{\text {a. }}$ ACS Med. Chem. Lett. 2012, 3, 48-52.

20. Moser, A.; Range, K.; York, D. M. Accurate Proton Affinity and Gas-Phase Basicity Values for Molecules Important in Biocatalysis. J. Phys. Chem. B. 2010, 114, 13911-13921. 
21. Haynes, W. M. CRC Handbook of Chemistry and Physics- Dissociation Constants of Organic Acids and Bases, 2010-2011. Josep A. DiVerdi-University of Colorado https://sites.chem.colostate.edu/diverdi/all courses/CRC\%20reference\%20data/dissociation\%20c onstants\%200f\%200rganic\%20acids\%20and\%20bases.pdf (accessed on March 5, 2020).

22. Kyrgowski, T. M.; Szatylowicz, H.; Zachara, J. E. How H-bonding Modifies Molecular Structure and $\pi$-Electron Delocalization in the Ring of Pyridine/Pyridinium Derivatives Involved in $\mathrm{H}$-Bond Complexation. J. Org. Chem. 2005, 70, 8859-8865.

23. Walba, H. \& Isensee, R. W. Acidity constants of some arylimidazoles and their cations. J. Org. Chem. 1961, 26, 2789-2791.

24. Jerez, G.; Kaufman, G.; Prystai, M.; Schenkeveld, S.; Donkor, K. K. Determination of thermodynamic $\mathrm{p} K_{\mathrm{a}}$ values of benzimidazole and benzimidazole derivatives by capillary electrophoresis. J. Sep. Sci. 2009, 32, 1087-1095.

25. a) A. H. M. Kirby and A. Neuberger, Biochem. J. 1938, 32, 1146. (b) Lenarcik., B.; Ojczenasz, P. J. Heterocyclic Chem. 2002, 39, 287.

26. Neis, C.; Petry, D.; Demangeon, A.; Morgenstern, B.; Kuppert, D.; Huppert, J.; Stucky, S.; Hegetschweiler, K. Inorg. Chem. 2010, 49, 10092.

27. Siewert, I.; Limberg, C. A. Trispyrazolylborato iron malonato complex as a functional model for the acetylacetone dioxygenase. Angew. Chem. Int. Ed., 2008, 47, 7953-7956.

28. Miao, C. B.; Wang, Y. H.; Xing, M. L.; Lu, X. W.; Sun, X. Q.; Yang, H. T. I2-Catalyzed Direct aHydroxylation of $\beta$-Dicarbonyl Compounds with Atmospheric Oxygen under Photoirradiation. J. Org. Chem. 2013, 78, 11584-11589. 